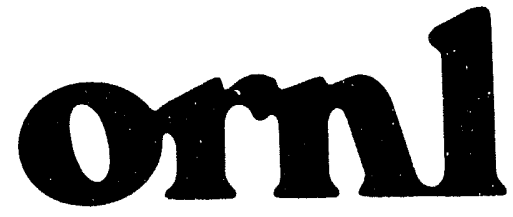

\section{OAK RIDGE NATIONAL LABORATORY}

MARTIN MARUETTA

\title{
Description of the Weatherization Assistance Program in Larger Multifamily Buildings for Program Year 1989
}

J. M. MacDonald

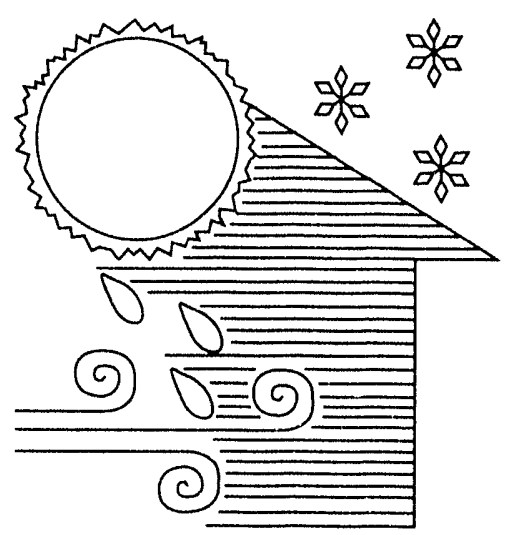

Weatherization Assistance Program 
This report has been reproduced directly from the best available copy.

Available to DOE and DOE contractors from the Office of Scientific and Technical Information, P.O. Box 62, Oak Ridge, TN 37831; prices available from (615) 576-8401, FTS 626-8401.

Available to the public from the National Technical Information Service, U.S. Department of Commerce, 5285 Port Royal Rd., Springfield, VA 22161.

This report was prepared as an account of work sponsored by an agency of the United States Government. Neither the United States Government nor any agency thereof, nor any of their employees, makes any warranty, express or implied, or assumes any legal liability or responsitility for the accuracy, completeness, or usefulness of any information, apparatus, product, or process disclosed, or represents that its use would not infringe privately owned rights. Reference herein to any specific commercial product, process, or service by trade name, trademark, manufacturer, or otherwise, does not necessarily constitute or imply its endorsement, recommendation, or favoring by the United States Government or any agency thereof. The views and opinions of authors expressed herein do not necessarily state or reflect those of the United States Government or any agency thereof. 
ORNL/CON-329

$\underline{\text { Energy Division }}$

\section{Description of the Weatherization Assistance Program in Larger Multifamily Buildings for Program Year 1989}

J. M. MacDonald

April 1993

Prepared for the

Weatherization Assistance Programs Division

U.S. Department of Energy

Prepared by the

OAK RIDGE NATIONAL LABORATORY

Oak Ridge, Tennessee 37831

Managed by

MARTIN MARIETTA ENERGY SYSTEMS, INC.

for the

U.S. DEPARTMENT OF ENERGY

under Contract No. DE-AC05-84OR21400 


\section{Contents}

LIST OF TABLES

LIST OF FIGURES

EXECUTIVE SUMMARY

ABSTRACT

ACKNOWLEDGMENTS

1. INTRODUCTION.$\quad$.

1.1 Overview of the Weatherization Assistance Program . . . . . . . . 3

1.2 Literature Review

1.3 Coverage of the Report

1.4 Obtaining Energy Use Data

2. DATA COLLECTION DESIGN

3. STATE GRANTEE SURVEY RESULTS

3.1 Strategic Partnerships

4. BUILDING SURVEY RESULTS

4.1 General Characteristics

4.2 Income, Elderly, and Handicapped

4.3 Geographic Distribution

4.4 Measures Installed

4.5 Measure Selection, Diagnostics, and Quality Control

4.6 Measure Costs

Page

iv

v

vi

ix

$\mathbf{x}$

1
3

6

6

7

9

11

13

15

18

18

19

22

22

5. NONENERGY PROGRAM IMPACTS

6. OVERALL RESULTS

6.1 Geographic Distribution of Multifamily Dwellings . . . . . . . . . 29

6.2 Advanced Programs

6.3 Discussion of the Low Level of MF Activity 30

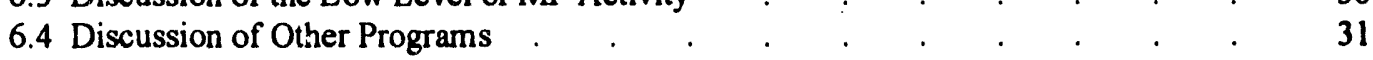

7. CONCLUSIONS \& RECOMMENDATIONS . . . . . . . . . . . $\quad 33$

REFERENCES . . . . . . . . . . . . . . . . . . 35

APPENDIX A - STATE GRANTEE SURVEY . . . . . . . . . . . . . A-1

APPENDIX B - BUILDING SPECIFIC DATA SURVEY . . . . . . . . B-1 


\section{List of Tables}

$\begin{array}{llr}\text { Table } 1 \text { Differences between whole and partial building weatherizations } \quad . \quad & 15\end{array}$

Table 2 Breakdown of installed measures for the sample $\quad$. $\quad . \quad$. $\quad . \quad 20$

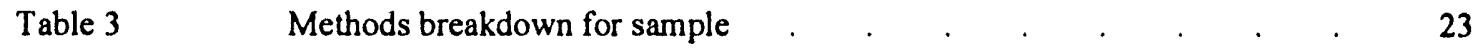

Table 4 Materials costs for the sample $\quad$. $\quad . \quad$. $\quad . \quad . \quad . \quad . \quad . \quad 23$

Table 5 Breakdown of material costs for units where measure was installed $\quad . \quad 25$

Table 6 Costs per dwelling for in-house, contractor, and mixed crews . . . $\quad 26$ 


\section{List of Figures}

Figure 1

PY 1989 level of MF weatherization activity indicated by Grantee responses

10

Figure 2

MF weatherization responses by agencies for PY 1989

Figure 3

Number of buildings and units by category of units weatherized per building

Figure 4

Year of construction for buildings weatherized in PY 1989

16

Figure 5

Heating fuel for 269 buildings and 2,000 residences weatherized in PY 1989

17

Figure 6

Building space heating system type

Figure 7

Building water heating system type

Figure 8

Distribution of income categories for weatherized dwellings

18

Figure 9

Geographic distribution of 269 buildings and 2,000 dwellings

weatherized in PY 1989

Figure 10

Distribution of materials costs by measure

Figure 11

Geographical distribution of 11,000 weatherized MF dwellings for PY 1989

Figure 12

Distribution of 20,000 dwellings by climate zone

30 


\section{EXECUTIVE SUMMARY}

The efforts of the U.S. Department of Energy (DOE) Weatherization Assistance Program (the Program) in larger multifamily buildings were examined for Program Year 1989. The results show that about 20,000 dwellings in these multifamily buildings were served under the Program that year. This is $9 \%$ of the total number of units served nationally, while costs were $7 \%$ of total national costs. High levels of activity in larger multifamily buildings were reported for some States, with New York accounting for half of all the residences treated. Owner investment is an important strategy in New York for improving their efforts.

A wide range of measures was installed, but the materials costs for the measures are dominated by the cost of windows ( $80 \%$ of the total for that year). Where the whole building was treated, $\$ 561$ was invested per unit, while for partial-building work the total invested was \$417. The energy savings and cost effectiveness of the Program were not estimated, because energy use and cost data adequate for developing such estimates could not be obtained (see Section 1.4 on Obtaining Energy Use Data).

\section{Background}

This report describes the nature and extent of weatherization activities under the DOE Weatherization Assistance Program in larger multifamily buildings (buildings with five or more dwelling units). DOE initiated this study to provide policy makers and program implementers with up-to-date, credible, and reliable information on the Program for making effective decisions. With assistance from Oak Ridge National Laboratory (ORNL), a National Evaluation of the Program was designed. The evaluation includes five studies overall, and this study is one of them. Two national surveys were conducted as part of this study: one of the States and one of local weatherization agencies. These data are the source for the results presented in this study.

\section{Findings}

The survey of the States yielded direct responses from 33 States. High levels of activity in multifamily buildings were reported for 11 of the 33 States. A few States indicated they do not have significant numbers of these types of buildings with more than $66 \%$ of the households income-qualified. New York is the only State which has conducted an evaluation of multifamily work under the Program in larger buildings in the past 10 years.

Special audit procedures for dealing with larger multifamily buildings were used by 9 of the 33 States. Strategic partnerships for multifamily buildings have been used or developed in 7 of the 33 States. The " $66 \%$ Rule" causes difficulty with qualifying buildings for eligibility under the Program in 6 of the 33 States. Policies regarding owner investment are 
in place for multifamily buildings in 11 of the 33 States, and 11 of the 33 States have considered or implemented policy changes regarding larger multifamily buildings recently. Nine of the 33 States offer some training related to field inspections of buildings and selection of measures to be installed that was felt to be applicable to multifamily buildings, with 6 of these States having very extensive training.

Overall, better understanding of "good" retrofit packages applicable to the Program (probably developed by region) appears needed. New York and Massachusetts provide important evidence that the impact of the Program for these buildings can be expanded. However, despite important improvements achieved to date, weatherization personnel from New York assert that much more still needs to be learned about the performance of measures in larger multifamily buildings, and they are currently working to plan additional research in this area.

\section{Recommendations}

Considering the importance of better information on measure performance and recent changes in States with advanced programs, specific recommendations are:

1. Begin initial case study evaluations of specific buildings and the measures installed in those multifamily buildings. A case study of one large multifamily building provides results for many dwellings that are specific to a State or region. The initial case studies should be conducted to better understand the current state-of-the-art in multifamily weatherization under the Program. These case studies should be selected from cities in States with significant levels of multifamily activity, such as New York, Illinois, Minnesota, and Washington.

2. The reporting of these the initial case studies should include a summary on the benefits of specific measures, groups of measures, field procedures, or management procedures found in the case studies. This summary should also include recommendations regarding measures or procedures that deserve further refinement or assessment.

3. The Program should change data reporting requirements for Grantees to include specification of the amount of work accomplished in larger multifamily buildings. This change is important for highlighting the importance and also the different nature of this sector. For both small and large multifamily, Grantees should report the number of multifamily residences that were not treated as part of the whole building.

4. The impact of partial-building work on cost effectiveness should be studied at some time in the future. Many States have building stock where only individual apartments can be retrofitted under rules of the Program, and the cost effectiveness of this partial retrofit work must be understood better to determine if it should be continued. 
5. Considerable expertise with multifamily buildings exists in some States. Transfer of this knowledge to other States that conduct multifamily work should be planned as the results of the case study work begin to be reviewed.

6. In addition to the knowledge gained from work conducted under the Program, the work of other organizations performing work in multifamily buildings should be considered relative to future refinement of procedures or measures used under the Program. For example, the work in Minneapolis and Chicago, cited in section 6.4 of this report, should be recalled when reviewing the case study results. Also, the work of Citizens Conservation Corporation, in Boston, should be examined, if access can be gained to their results.

7. Program procedures should be changed to effectively capture the energy savings to be found from common area or "house" lighting in these multifamily buildings. The savings from these lighting retrofits are important, and crews should attempt to achicve these savings while they are in a building, if the whole building is included in the work. 


\title{
Description of the Weatherization Assistance Program in Larger Multifamily Buildings for Program Year 1989
}

\author{
J. M. MacDonald
}

\begin{abstract}
This report describes the nature and extent of weatherization activities under the U.S. Department of Energy (DOE) Weatherization Assistance Program (the Program) in larger multifamily buildings that have five or more dwelling units. DOE initiated this study to provide policy makers and program implementers with up-to-date, credible, and reliable information. Two national surveys were conducted as part of this study. The results from the two national surveys show the Program to have served about 20,000 dwellings in Program Year (PY) 1989. These 20,000 dwellings represent about $9 \%$ of the total number of units weatherized that year. The total costs for the Program efforts in these buildings are about $7 \%$ of total national costs for the Program. The energy savings and cost effectiveness of the Program were not estimated, because adequate energy use and cost data could not be obtained. Materials costs for the Program in multifamily buildings in PY 1989 are dominated by the cost of windows ( $80 \%$ of the total). The Program should begin ongoing case study evaluations of specific buildings and measures for these buildings to better understand the current state-of-the-art in multifamily weatherization under the Program, increase understanding of the performance of measures, and capture useful knowledge that can be transferred to other locations.
\end{abstract}




\section{ACKNOWLEDGMENTS}

Members of the National Weatherization Evaluation's working groups helped design this study, guide its implementation, and interpret its findings. The author is grateful for their contributions and would like to acknowledge them individually:

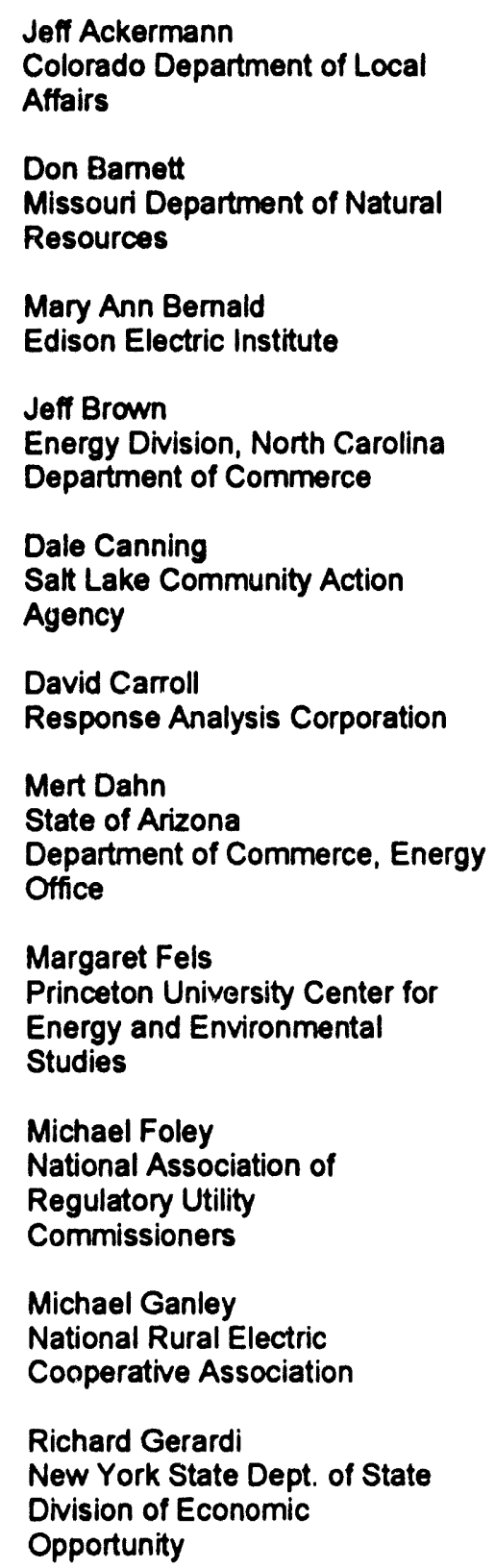

Sharon Gill
U.S. Department of Energy,
Chicago Support Office
Larry Goldberg
Sequoia Technical Services
Miriam Goldberg
U.S. Department of Energy,
Energy Information
Administration (EIA)
Judy Gregory
Center for Neighborhood
Development
Al Guyant
Public Services Commission
of Wisconsin
Martha Hewett
Center for Energy and
Environment
Bion Howard
Alliance to Save Energy

Larry Kinney
Synertech Systems Corporation

Judith Lankau
Orange and Rockland Utilities

Leon Litow

U.S. Department of Health and Human Services

\section{Ron Marabate}

Michigan Department of Labor

Bureau of Community Services

Jane Marden

American Gas Association
Phil Mihlmester

Aspen Systems Corporation

John Mitchell
Consolidated Edison Company,
Inc.

Barry Moline

American Public Power

Association

John Nelson

Wisconsin Gas Company

Karl Pnazek

Director, CAP Services

Meg Power

National Community Action

Foundation

Bill Prindle

Alliance to Save Energy

Ken Rauseo

The Commonwealth of Massachusetts

Jeffrey Schlegel

Wisconsin Energy Conservation

Corporation

Ken Tohinaka

Vermont Energy Investment Corp.

Wendel Thompson

U.S. Department of Energy (EIA)

Marjorie J. Witherspoon

National Association of State

Community Services Programs 
Jeanne Van Vlandren, the Director of DOE's Weatherization Assistance Program, has provided important guidance to the overall study and support for continued improvement to DOE's efforts in larger multifamily buildings. Darrell Beschen (the original DOE Project Manager for this study) helped define the overall goals of this study. Marilyn Brown, the manager of the overall National Evaluation effort at ORNL, also helped define the goals of this study, and she provided important comments on the content of this report. Aspen Systems Corporation, a subcontractor, provided the major support to the study for data collection and input from the local weatherization agencies and for the effort to collect energy use data from utilities and building owners.

This study could not have been completed without the cooperation of local and State weatherization program managers and the DOE Regional Support Offices, who took time away from their busy schedules to provide data and other assistance to the National Weatherization Evaluation. The input received from all of these individuals is greatly appreciated. 


\section{INTRODUCTION}

This report describes the nature and extent of weatherization activities under the U.S. Department of Energy (DOE) Weatherization Assistance Program (the Program) in larger multifamily buildings. For this study, a multifamily unit is defined as a dwelling that is located in a structure containing more than four residences that are not located in row-housing (which includes townhouses). The nature of these activities will be described in terms of what measures are being installed, what procedures are used to select those measures, and what costs are incurred for installation of the measures. The extent of the program will be described in terms of how many States and agencies perform work on multifamily buildings and how many agencies and States use different procedures.

Little information is available on the effectiveness of weatherization procedures in these larger buildings, partly because the more complex building systems and the larger number of occupants per building mak e dealing with these buildings more difficult. Very few impact evaluation data exist for these buildings. ${ }^{1}$ The study reported here also does not provide empirical information on cost effectiveness for the Program activities described.

Larger multifamily buildings represent about $15 \%$ of the 94 million residences in the country in 1990 (all income groups), and they account for about $9 \%$ of the 16.5 quads of total annual residential energy use (EIA 1993) on a source basis (where electricity is converted at $11,600 \mathrm{Btu} / \mathrm{kWh}$ to account for generation and transmission losses). In comparison, single-family and small multifamily (those with 1-4 dwellings per building) together account for about $80 \%$ of all residences and almost $90 \%$ of residential energy use (again, all income groups).

Residences in multifamily buildings with 5 or more units were previously estimated to account for about one-third of all Program-eligible renter-occupied residences (The Economic Opportunity Research Institute, Inc. 1986), based on the 1984 Residential Energy Consumption Survey (RECS) data (EIA 1986). Estimates made for this study based on the 1987 RECS data (EIA 1990) show that eligible ${ }^{2}$ renters in larger multifamily buildings that are not in public housing projects account for about 3.5 million households. These 3.5

1. Tom Wilson, of Synertech Systems Corp, in Syracuse, New York, conducted a major literature review in 1990 for the State of Michigan on "Multifamily Weatherization Research," and he has communicated to us that no evaluation results covering work in larger multifamily buildings under the Program were available for that study.

2. Defined as households earning less than $150 \%$ of poverty-level income. 
million represent $15 \%$ of all eligible households not in public housing and $33 \%$ of all eligible renter-occupied residences not in public housing projects. (Public housing weatherization improvements are funded mostly through the U.S. Department of Housing and Urban Development.) The 1987 RECS results confirm the earlier estimates based on the 1984 RECS data, and results for the 1990 RECS (now HECS) data are expected to be similar.

DOE initiated this study to provide policy makers and program implementers with up-to-date, credible, and reliable information on the Program for making effective decisions. With assistance from Oak Ridge National Laboratory (ORNL), a National Evaluation of the Program was designed. The evaluation is comprised of three "impact" studies and two "policy" studies (Beschen and Brown 1991). The three impact studies are focused on energy-savings and cost-effectiveness performance of the Program in three key markets:

- Single-family and small multifamily study (Single-Family Study, Berry et al 1991)

- Fuel-oil study of single-family homes in nine Northeastem States (Fuel-Oil Study, Ternes et al 1992)

- Larger multifamily study of buildings with five or more dwelling units per building (Multifamily Study, the study reported here)

The data collected for the Single-Family Study and the Fuel-Oil Study have permitted evaluation of the nature of the people and buildings served, the measures installed, the energy saved, cost effectiveness of the measures, and other factors. The data obtained for the Multifamily Study have shown limited penetration of the Program to multifamily buildings. In addition, obtaining energy use data from records as far back as 1988 (the pre-retrofit year for the Program in 1989) was not possible without great difficulty. Because of this difficulty, few energy use data were obtained, and the energy savings and cost effectiveness results could not be completed for larger multifamily buildings (see Section 1.4 on Obtaining Energy Use Data).

Thus, the Multifamily Study is essentially a supporting study. The other two supporting studies on policy from the National Evaluation address the characteristics of the Program network (Mihlmester et al 1992) and a profile of low-income weatherization resources and the population already wes therized (Power et al 1992). Together the five studies comprise the National Evaluation of the Weatherization Assistance Program. The Multifamily Study is the most exploratory of the five, since much less is known about how the Program deals with these larger buildings and the extent of services provided by the Program to these buildings. 


\subsection{OVERVIEW OF THE WEATHERIZATION ASSISTANCE PROGRAM}

Federal efforts to weatherize the homes of low-income people began as far back as 1973, and efforts have progressed through several legislative authorizations to the present program conducted under the responsibility of the DOE. The goals of the Weatherization Assistance Program include: increase the energy efficiency of low-income households, reduce the impact of high energy costs on low-income households, and improve the health and safety of those residences, particularly those of the elderly, the handicapped, and families with children. (A more extended overview of the Program is provided in the evaluation results for the Single-Family Study, Brown et al 1993.)

The Program provides formula grants and operates in a decentralized fashion. Federal grants are negotiated with States which, in turn, provide grants to local agencies (approximately 1,100 for all States and the District of Columbia). The local agencies actually perform or contract for the weatherization work performed at individual homes. (Extensive information on States and agencies can be found in Mihlmester et al 1992.)

Total expenditures by full-scale weatherization programs throughout the country between 1978 and 1989 are estimated to be $\$ 4.4$ billion (Power et al 1992). In addition to DOE, other sources such as utilities, the U.S. Health and Human Services Department, and the States also provide funding for these activities. Nevertheless, most funds are spent under DOE rules for the Program.

\subsection{LITERATURE REVIEW}

A major review of multifamily retrofit efforts was completed by Goldman et al in 1988 . This review covered many types of retrofits in larger multifamily buildings and provided some important insights regarding the factors affecting cost effectiveness of multifamily retrofits. Savings were found to range from 10 to $30 \%$ of pre-retrofit consumption. Some exceptional savings of $50 \%$ of energy use were observed, but in other cases savings were low. The review showed the uncertainty of energy savings for specific buildings and the importance of heating system retrofits for central heating systems. This review did not cover any buildings that received retrofits under DOE's Weatherization Program, so direct information on the Program is not available from this source. However, the insights provided by this review are applicable to the Program to some degree, and these insights will be discussed as appropriate in following sections.

More information is available from other sources on the benefits of retrofits installed in multifamily buildings. However, most sources available do not cover buildings that 
received retrofits under the Program. Thus, previous evaluations of programs for larger multifamily buildings are, for the most part, not directly applicable.

Evaluations of efforts under the Program in multifamily buildings have been located only for New York City and Seattle. The New York City results are brief and simple; they cover 12 large oil-heated buildings only, having a total of 570 dwelling units. The results, unadjusted for any control group, were that the buildings had an average annual savings of $17 \%$, which is similar to results obtained for the Fuel-Oil Study (Ternes et al 1994) in single family residences. The Benefit/Cost ratio for the New York multifamily buildings, for only the DOE investment (not including owner investment of $\$ 222,000$ out of $\$ 713,000$ total), is 2.56 , with a standard deviation of 1.57 (Synertech 1991). No extended analysis of these buildings was performed.

A very extensivs evaluation addressed work directed toward all-electric multifamily buildings in Seattle (Okumo 1991). Work conducted for Seattle City Light under Program procedures was evaluated side-by-side with a program run by the utility for multifamily buildings that did not qualify as low-income. Thus, two main treatment groups of buildings (for two cohort time periods) were evaluated: standard-income and low-income. Apparently, the low-income buildings were treated essentially as if they were treated under the Program, although the second low-income cohort appears to have been modified to include some significant common area lighting measures. The utility paid for all measures in low-income buildings, with a guarantee that rents would not be raised for five years, and provided very generous no-interest loans to standard-income building owners for installation of measures.

The types of measures installed in the two side-by-side programs varied, as the buildings weatherized under the Program received fewer lighting retrofits to common areas, fewer low-flow showerheads, and more safety and security measures. These Program buildings also were more likely to have venting and caulk/weatherstrip installed. Windows were installed in almost all buildings. The range of installed costs were $\$ 272$ to $\$ 2,605$ per unit for standard-income buildings and $\$ 432$ to $\$ 3,612$ for the low-income buildings.

Okumo concludes that buildings weatherized under the Program had a net savings (after control group adjustment) of 4 to $9 \%$, while standard-income buildings had a net savings of 13 to $18 \%$ of pre-retrofit energy use. Savings are evaluated for the whole building, for common area lighting retrofits, and for dwelling unit measures. She concludes that common area lighting measures should be emphasized, as they produced a big savings at a low cost. The lighting retrofits appeared to have an important role in the differences between standard-income and low-income building results. 
For the dwelling unit measures, her analyses indicate that windows probably provided $70 \%$ of the total thermal energy savings. She implies that other dwelling unit measures, which included insulation, venting, pipe/duct insulation, caulk/weatherstripping, misc./repair, and inspection and possible replacement of knob-and-tube wiring, need better optimization. Repair measures and knob-and-tube wiring work were generally not part of the work performed on standard-income buildings. Also, very little caulking and weatherstripping, much less venting, and much less pipe/duct insulation (typically to domestic water piping) were installed in standard-income buildings. Many of these measures do not contribute significantly to energy savings.

Cost effectiveness of measures in Seattle were estimated, and the net levelized cost (after control group adjustment) of all measures for low-income buildings is generally around $\$ 0.10 / \mathrm{kWh}$ for both the first and second year the program was run, while the levelized cost for all measures in standard-income buildings is reduced from $\$ 0.075 / \mathrm{Kwh}$ the first year to $\$ 0.056 / \mathrm{kWh}$ the second year.

For dwelling unit measures, a calculation of the energy saved for each measure showed the net levelized cost for windows to be reasonably equivalent for both low-income and standard-income buildings, but windows were generally not cost effective, with levelized costs ranging from $\$ 0.060-0.130 / \mathrm{kWh}$ (assuming $70 \%$ of thermal savings is attributed to windows). Several models of windows savings were formulated and tested, and these models indicate savings for the windows of about $70 \%$ of total electricity savings, although these results require further verification. Okumo also suggests that advances in window technology can be expected to improve results for windows, but specific advances are not explicitly stated. For other dwelling unit measures besides windows, the net levelized cost for low-income buildings, at $\$ 0.050-0.075 / \mathrm{kWh}$ saved, was two to three times as high as the levelized cost for standard-income buildings. Okumo concludes that the causes of these differences should be explored, although the major factor for the differences may be the investment by the low-income program in several measures that contributed little or nothing to energy savings.

These two reports provide a mixed picture of results achieved in larger multifamily buildings in somewhat similar climates with approximately similar investment levels (the value for New York is $\$ 1,250$ per unit). The New York Program deals with low-income buildings which typically have hot water or steam boilers providing heat, while the Seattle buildings are all-electric. Details on the measures installed in New York are not known, but the results of this study and contacts with people working in New York City indicate that work on heating systems is important to achieving significant savings. The national review of multifamily programs (Goldman 1988) also indicated that heating systems work was important to achieving good results. 
The New York data suggest that the Program is cost effective there, while the Seattle results indicate that the Program was not cost effective by their regional criteria. The difference in heating systems appears to be a potential major factor accounting for this difference. Differences by region are important for understanding the Program and results achieved under the Program for multifamily buildings.

\subsection{COVERAGE OF THE REPORT}

This report describes the data collection design, presents results of the survey of the States and of the survey of local agencies, presents a discussion of the overall results, and provides conclusions and recommendations. The results from local agencies include detail on the types of buildings served, the measures installed, technical methods used, and measure costs. Adequate energy use and cost data for an analysis of energy savings and cost effectiveness could not be obtained, and no estimate is made of cost effectiveness for the Program.

\subsection{OBTAINING ENERGY USE DATA}

A significant amount of work was conducted in this study to obtain energy use and cost data needed to estimate cost effectiveness for the Program. The major stumbling block to obtaining these data occurs when the data move from on-line electronic form in a computer system to archival status. Once data are archived, the costs and personnel time required to retrieve the data increase dramatically. Retrieval then becomes very difficult because of resource constraints (usually the personnel time is not available to achieve the retrieval). Thus, the primary lesson for researchers who wish to obtain and use energy use data is to obtain the data before they are archived, which is typically 12 to 18 months from the present. If a study is designed to obtain these data before they are archived, data collection should begin as soon as possible after the data collection design is completed, and the data collection design should recognize the 12 to 18 month limitation. 


\section{DATA COLLECTION DESIGN}

As part of the Single-Family Study, a national survey of a sample (about 400) of the approximately 1,100 subgrantees operating across the country was conducted. Because the study is designed to estimate the impacts of the Program (and not the impact of other programs that fund weatherization), the sample was restricted to dwellings weatherized entirely, or in part, with DOE funds or with funds from other sources (such as Oil Overcharge or Stripper-Well) used according to Program regulations. Thus, dwellings weatherized entirely with Low-Income Home Energy Assistance Program (LIHEAP) funds were not included in the sample if they were not administered according to Program regulations.

The sampling design used in the national survey is described in the Single-Family Study Experimental Plan (Berry et al 1991). To ensure thorough geographic coverage, the continental United States was divided into ten subregions, each comprised of three or more States, and the sample was drawn proportionately from each region.

While approximately one third of the nation's subgrantees were sampled, the largest 10 local agencies of the Program (with the greatest number of households weatherized in PY 1989) were included. However, dwellings for these larger agencies were sampled at only half the rate at which dwellings for other agencies were sampled. These large agencies tend to serve large metropolitan areas. Overall, a disproportionate number of multifamily units were expected to be in the sample.

Data were collected for a sample of the dwellings weatherized under the Program and a control group was to be used to adjust for factors outside the actual weatherization. The control group consists of dwellings on the waiting lists of agencies for future weatherization work.

Based on information received from the national survey of the Single-Family Study, data on weatherization of larger multifamily buildings were requested from 109 agencies (out of about 400) that appeared to have performed work in these larger multifamily buildings. In addition, survey data were collected from States to assess the approach taken by States toward these multifamily buildings and the guidelines and training support provided for multifamily buildings (the survey instrument is shown in Appendix A).

A survey instrument was developed for the Single-Family Study to obtain dwelling-specific data (Berry et al 1991). This form was field tested with several agencies and feedback from the agencies was used to refine that form. The form for the Single-Family Study was used as a starting point for developing a dwelling-specific survey form for the Multifamily Study. Only minor modifications were needed. The multifamily form was field tested with 
four agencies and two consulting firms, and feedback from these organizations was used to make final modifications to the form before it was sent to agencies to obtain dwelling-specific cata.

The dwelling-specific data on weatherized dwellings in multifamily buildings include significant descriptive information on the buildings weatherized, the measures installed, and the procedures used to provide the weatherization services (the survey instrument is shown in Appendix B). Energy use data were requested from utilities and building owners across the country for both treatment and control group buildings. The return rate for the treatment group characteristics data is fairly good (about $70 \%$ for dwellings that were truly in larger multifamily buildings), while the return rate for the requested energy use data is very poor (less than 5\%). The energy use data needed for this study extended back several years and were very expensive to process. Thus, few data were obtained, and the energy savings and cost effectiveness analyses have not been conducted at this time. The results obtained from the treatment group descriptive data are presented in this report.

The sampling design for the Single-Family Study had one major shortcoming relative to understanding the Program work performed in PY 1989 in larger multifamily buildings: New York is not represented as well as it should be (the data following show New York to account for over half of all work in PY 1989). To address this shortcoming, additional survey data (using the same agency survey instrument) were collected from another agency in New York to check against our analysis. Although the additional data are not included directly in the analysis because they were received after the analysis data set had been developed and finalized, these data were checked to confirm that calculated values were reasonable in comparison with these additional data (that were not used directly).

The State-level data collected indicate that States often do not track larger multifamily buildings separately from smaller multifamily buildings (those with less than five dwellings per building), and agencies also sometimes confused smaller with larger multifamily buildings. Overall, the results of this study show that weatherization of larger multifamily buildings under the Program is not a large part of the total program, as presented in the following sections of this report. 


\section{STATE GRANTEE SURVEY RESULTS}

A survey (Appendix A) was sent to 48 States, not including Alaska and Hawaii, to obtain some overview information on activities of the Program relative to larger multifamily buildings. The survey was returned by 33 States (two-thirds response) and the survey responses appear to provide a reasonable picture of the position of multifamily buildings in the Program.

In addition to the Grantee survey, a survey of agencies was also conducted (described in next section). As a result, numerous contacts were made with agencies and State Program offices in many States during the course of the study to discuss different facets of the study. The contacts led to much informal, verbal information about the nature of the Program for multifamily in most States. Only about 5 States are not represented to some degree. The extent of Program efforts in large multifamily are also quantified in the Network Characterization report (Mihlmester 1992), where large multifamily buildings were estimated to account for $6 \%$ of total residences weatherized under the Program in PY 1989. Based on these contacts and the supporting information generated by other studies in the National Evaluation, apparently few States with any sizable amount of work in multifamily buildings did not respond - Maine and California may be the only two of importance.

The most difficult part of analyzing data received for this study has resulted from the difficulty States and weatherization agencies sometimes have in distinguishing between small multifamily (buildings with 1-4 units) and larger multifamily buildings. Since DOE does not require States to keep records on the differences between these types of multifamily buildings, many States simply do not have the data. Thus, they are forced to estimate, or they force the estimating effort back to the requester. Many times the distinction between small and large multifamily appears to have been ignored. As a result, adjustment of the data is sometimes required, although these adjustments do not change the overall results much.

The raw response from the 33 States to the survey (including several estimates by States and by ORNL) show a total of 21,000 larger multifamily units weatherized by the Program in Program Year (PY) ${ }^{1}$ 1989. However, 2,000 or more of these units are in public housing, and perhaps 1,000 are not truly dwellings in large multifamily buildings. Thus, these data show a total of about 18,000 units weatherized in larger multifamily buildings that are not in public housing and about 2,000 units weatherized in public housing multifamily buildings. Based on knowledge of the level of activity in States obtained through extensive

1. Program Year (PY) 1989 typically began in April 1989 and ended in March 1990. 
interactions (including Maine and California), the Network Characterization Study results, and the Grantee responses here, a reasonable estimate of the total number of units served nationally under the Program in PY 1989 that are not in public housing is about 20,000 units. A map of the country showing the raw Grantee responses is shown in Fig. 1.

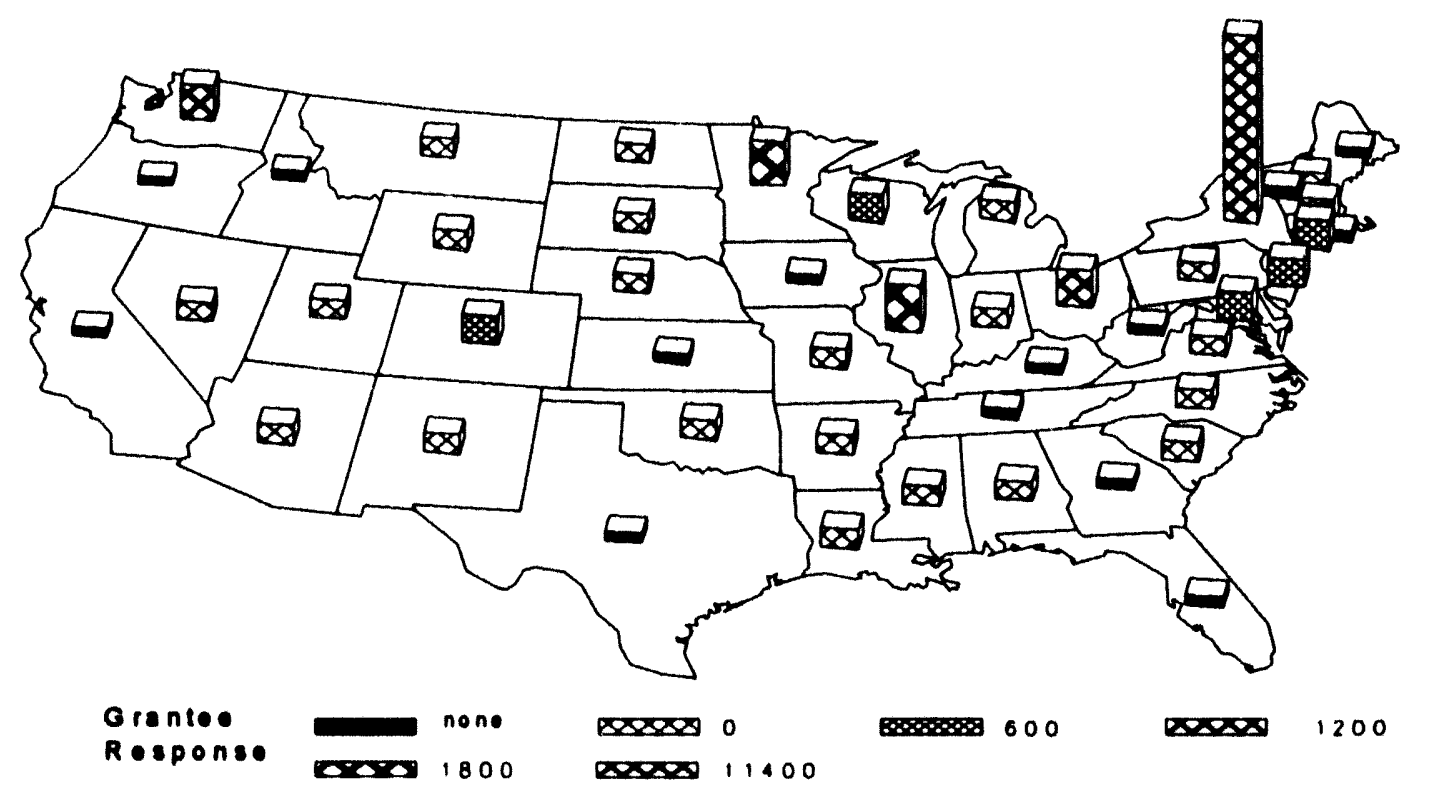

Figure 1 - PY 1989 level of multifamily weatherization activity indicated by Grantee responses.

The very short bars indicate no response. The tall bar for New York represents over 11,000 units weather. ized. Some other States had over 1,000 units served, but New York accounted for over half of the total.

The bars on the map indicate levels of response, with taller bars showing many units weatherized and the very short bars showing no response or no dwellings served. New York dominates the number of units served in PY 1989, with over 11,000. New York also provided significant material concerning the methods used there to serve larger multifamily buildings.

Over 200,000 residential units of all types were weatherized in PY 1989 by local agencies using all types of funding (Mihlmester et al 1992). In planning for the National Evaluation, all agencies were surveyed to determine how many dwellings were weatherized using the criteria specified in the first paragraph of Section 2, Data Collection Design. The results of this survey showed that, with these funding criteria, 198,000 dwellings were weatherized in PY 1989 (Brown et al 1993). Using 198,000 single-family and small multifamily residences together with the additional 20,000 larger-building multifamily residences estimated here to be weatherized under the Program in PY 1989 leads to an overall total of interest of about 220,000 dwellings weatherized. The 20,000 larger-building multifamily residences represent $9 \%$ of this total. 
The other information obtained from the State Grantee Survey shows that:

- High levels of activity in multifamily buildings were reported for 11 of the 33 States. A few States indicated they do not have significant numbers of these types of buildings which house qualified households.

- Some States do not have enough funding under the Program to even consider doing a larger multifamily building, as one building could require anywhere up to the entire annual funding of a given agency.

- New York is the only one of the 33 States which has conducted an evaluation of work conducted under the Program in multifamily buildings in the past 10 years.

- A special type of audit procedure for dealing with the differing audit requirements for some larger multifamily buildings was indicated for 9 of the 33 States.

- Strategic partnerships (see following section) of some type for performing weatherization work on multifamily buildings have been used or developed in 7 of the 33 States.

- The " $66 \%$ Rule" causes difficulty with qualifying buildings for eligibility under the Program in 6 of the 33 States.

- Policies regarding owner investment are in place for multifamily buildings in 11 of the 33 States.

- Similarly, 11 of the 33 States have considered or implemented policy changes regarding larger multifamily buildings recently.

- Nine of the 33 States offer some training related to field inspections of buildings and selection of measures to be installed that was felt to be applicable to multifamily buildings, with 6 of these States having very extensive training.

- Ten of the 33 States indicated that DOE policies for the Program should be changed to improve the services that could be offered to multifamily buildings, including

- Allow high efficiency lighting in common areas

- Reduce $66 \%$ rule to $50 \%$ majority

The sentiment for the lighting change was very strong, and the sentiment for changing the $66 \%$ rule was moderate.

\subsection{STRATEGIC PARTNERSHIPS}

The strategic partnerships that have been formed in seven States are primarily with utilities and with other government organizations. Responses indicated that some of these partner- 
ships are in the formative stage, and other comments on the survey forms suggested that more such partnerships may form in the future. The most advanced partnership appears to be the New York City Weatherization Coalition, where all weatherization work in large multifamily buildings is being coordinated through one organization and all partnerships with utilities and others generally go through this one coordinating organization. In Seattle, where we have already described some interaction with Seattle City Light and the weatherization organizations, funding from several sources is merged to achieve combined efforts on weatherization, housing rehabilitation, and tenant education. 


\section{BUILDING SURVEY RESULTS}

Based on responses to the national survey conducted under the Single-Family Study, we initially identified about 6,000 dwelling units weatherized under the Program in multifamily buildings. These data were used to send out a survey on building-specific information (the survey instrument is shown in Appendix B) to 109 agencies across the country. However, the responses to the building-specific data request showed large attrition of this sample due to improper identification of dwellings as being in larger multifamily buildings. In addition, many agencies could not respond due to financial difficulties or inability to locate records. Some agencies simply did not respond. The overall attrition from this initial sample was high:

- Dwelling was incorrectly identified as multifamily (about $20 \%$ )

- Agency did not respond due to lack of records, financial difficulty, or other reason (about $25 \%$ )

Thus, overall about $45 \%$ of the sample was lost to these two factors. The presence of public housing units in the data also complicated estimates, as about $20 \%$ of the dwelling units for which data were requested were in public housing. These two factors led to a final sample of units, not in public housing, of only about 2,000 ( $35 \%$ of our original data request). The distribution of these approximately 2,000 dwelling-specific responses (that do not include public housing) is shown in Fig. 2.

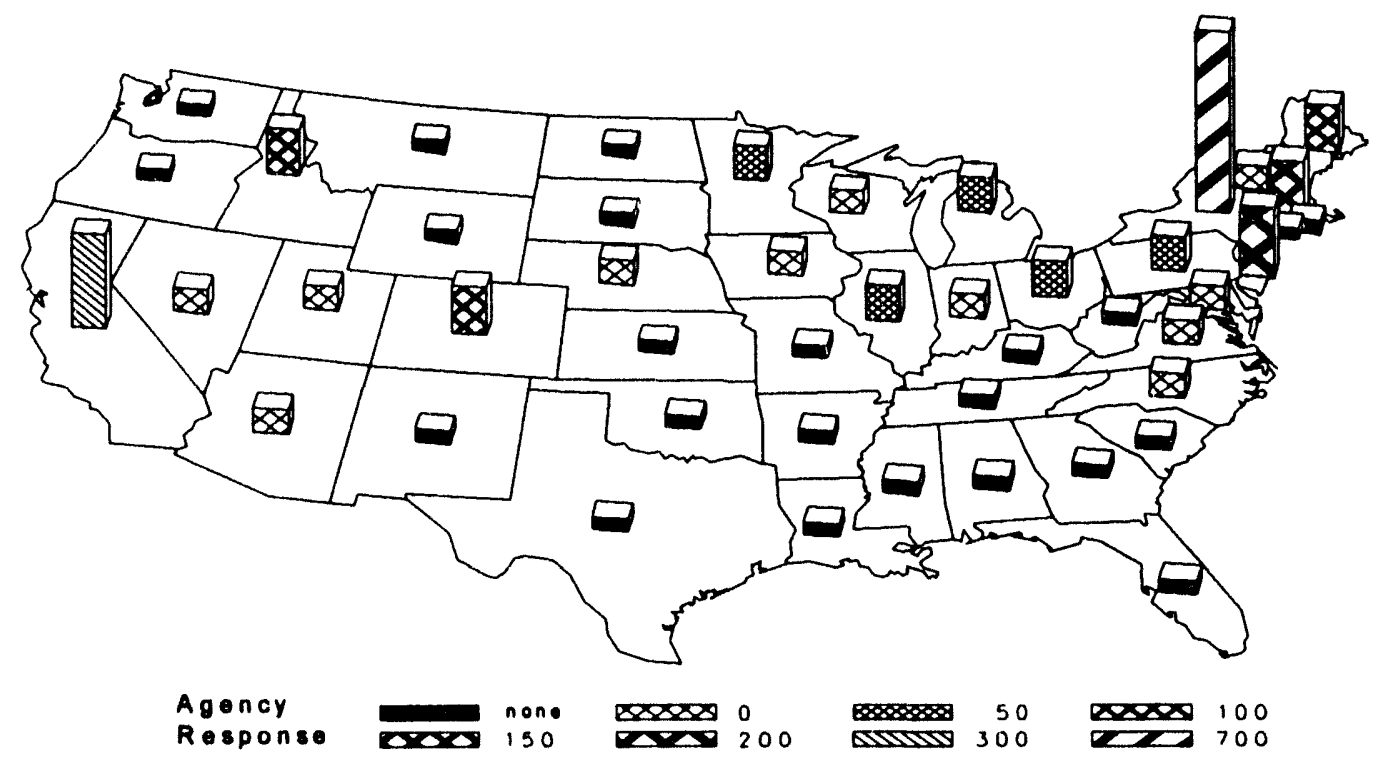

Figure 2 - Multifamily weatherization responses by local agencies for PY 1989.

The very short bars indicate no response or no data requested, and the next tallest bar represents a few units. The tall bar for New York represents a little over 700 units weatherized. 
The sample obtained (about 2,000) represents $10 \%$ of the 20,000 units not in public housing estimated to have been weatherized in PY 1989. The Single-Family Study (Brown 1993) obtained data on 14,971 dwellings, which are about $7.5 \%$ of the 198,000 dwellings of interest in that study. For this study, data for about 1,100 dwellings in New York City were obtained, but only 700 were included in the working data set, as the additional data arrived after the analysis was partially complete. (Including the additional data would have increased the working set size to about 2,400 dwellings.) However, the data on all 1,100 were checked by hand to provide some assurance that results obtained for the 700 were not unreasonable for the 1,100 . Thus, the sample data for New York City are representative of $10 \%$ of the units served there in PY 1989.

The data on these 2,000 dwellings describe Program Year 1989, and may not be representative of more recent years. During the course of contacts with States and agencies, many changes taking place relative to multifamily buildings were mentioned. Some agencies were reducing their multifamily work as oil overcharge funds were depleted, while other agencies were considering expanding their multifamily work.

The dwelling units in public housing that were weatherized (usually partially) under the Program in PY 1989 are dominated by units in Chicago and Baltimore, where 1200-1400 dwellings were weatherized for both together. The public housing weatherizations appear to be performed through informal partnerships with local (city) public housing authorities, where different parts of the weatherization work are performed under DOE and public housing funds.

The responses displayed in Fig. 2 were obtained from 54 local agencies representing 269 buildings and 2,050 weatherized dwelling units in 24 States. Responding agencies were asked to indicate the total number of units located in a specific building which received weatherization measures. In some cases the respondents may have indicated that the entire building was not weatherized and failed to provide the total number of units located in the building. A total of about 3,200 dwelling units were reported by the agencies for the 269 buildings, and the data suggest that the total number of units (adjusting for missing entries) in the weatherized buildings is about 3,600 .

No sampling weights were used, so the tabulated and graphed results represent the data as received. Weighting is problematical in that national data specific to larger multifamily buildings are more limited, the number of buildings served (269) is small, and the Program does not track data to allow better determination of which agencies perform work in larger multifamily buildings. Given these factors, weighting might potentially hurt more than help. 
Given the attrition that occurred, there is potential for attrition bias. However, the data cover 24 States, and New York appears to be represented acceptably. The 54 agencies represented by the data may account for over $80 \%$ of all agencies dealing with larger multifamily buildings in the country, based on interactions with the States and agencies. However, there is no firm basis for this $\mathbf{8 0 \%}$ value. Attrition bias may be present in the sample to some degree, but the sample appears to be reasonably representative.

About half the buildings in this sample are more than 50 years old, and they range in size up to 160 dwellings. The mean building size is 13.5 dwelling units (with $75 \%$ having 12 or fewer units), and the mean number of units weatherized is 7.6. For comparison, New York City has very large buildings, and the average building size there is between 35 and 40 units. There are two distinct groups of buildings in the sample: those where the whole building was weatherized and those where only part of the building was done (Table 1). When the whole building was weatherized, an average of 15 dwellings are served. But when only part of the building is weatherized, an average of 2-3 units are served while the building size is about 12 units.

\begin{tabular}{|l|c|c|c|}
\hline \multicolumn{4}{|c|}{ Table 1. Differences between whole and partial building weatherizations } \\
\hline & No. of buildings & Average units weatherized & Total units per building \\
\hline Whole & 111 & 15 & 15 \\
Partial & 158 & 3 & 12 \\
\hline Total & 269 & 7.6 & 13.5 \\
\hline
\end{tabular}

Note: Missing data cause some variation in units per building, so these values are approximate.

There are many reasons why the whole building is not weatherized, including each dwelling having an individual heating system, which lessens the benefits of whole building work. Another major reason agencies do not weatherize whole buildings is difficulty in qualifying buildings to meet rules of the Program (66\% of the applicants must be incomequalified before work can be performed on the whole building).

\subsection{GENERAL CHARACTERISTICS}

Categories of the number of buildings and the units weatherized per building are shown in Figure 3. Many buildings had less than ten units weatherized, but the total number of units weatherized is more even across the categories, because larger buildings had many units in them. The distribution of weatherized buildings by year of construction is shown in Fig. 4. The largest number of buildings reported construction dates from 1920 to 1929. The next largest was for the period after 1979. 

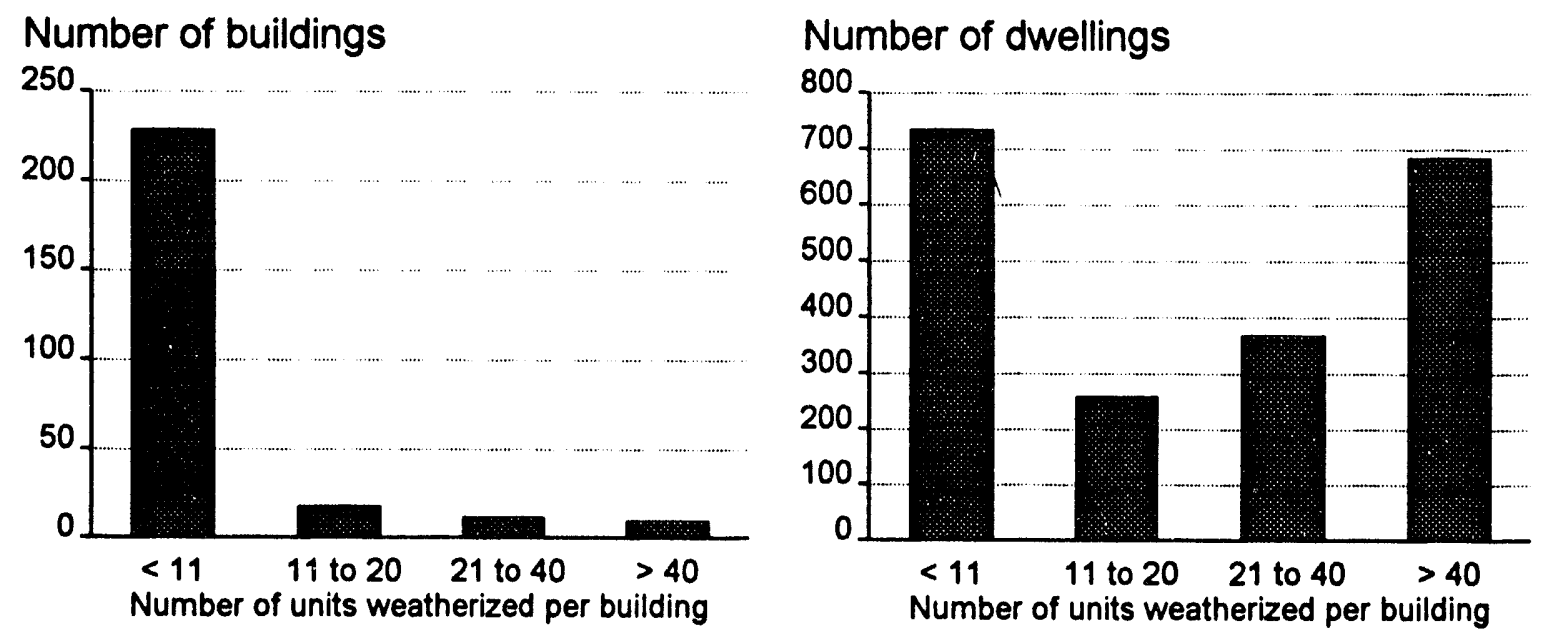

Figure 3 - Number of buildings and units by category of units weatherized per building.

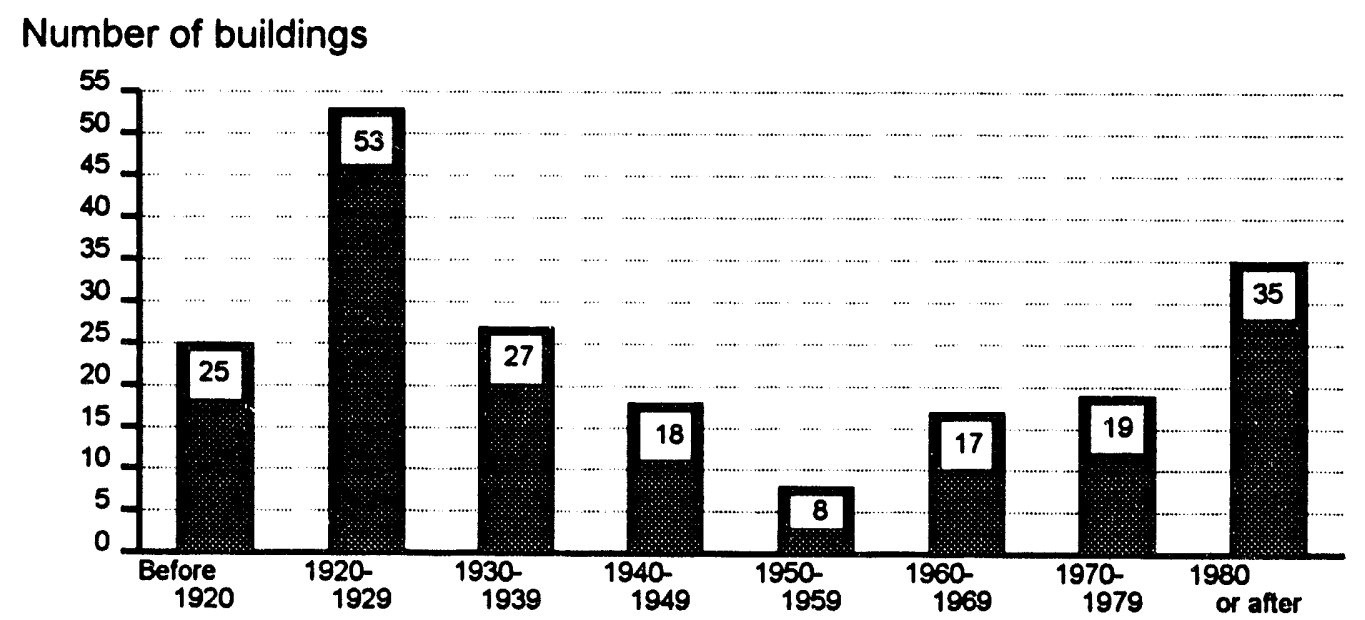

Figure 4 - Year of construction for 202 of 269 buildings weatherized in PY 1989.

The percentage of buildings and dwellings by primary heating fuel are shown in Fig. 5 . Natural gas is the dominant fuel, but significant use of fuel oil and electricity is also found. Supplemental fuels are not significant. The types of heating systems in these buildings (shown in Fig. 6) were: $32 \%$ with central heating plants for the building or complex, $30 \%$ with individual central systems in each apartment, $20 \%$ with in-space electric or fossil-fuel heaters, $7 \%$ with some other heating arrangement (such as combinations of the previous systems), and $11 \%$ of the systems were unknown by the agencies. Central air conditioning systems were present in 13 buildings (one for the whole building and 12 for individual apartments). Some window air conditioners or heat pumps were present in about $40 \%$ of the buildings. 
The type of domestic hot water system (Fig. 7) was not known for $23 \%$ of the buildings. Central hot water systems for the whole building were present in $32 \%$ of the buildings, and $36 \%$ of the buildings had individual hot water systems in the dwelling unit. Central hot water systems by floor of the building were present in $4 \%$ of the buildings, and the remaining few percent were other types.
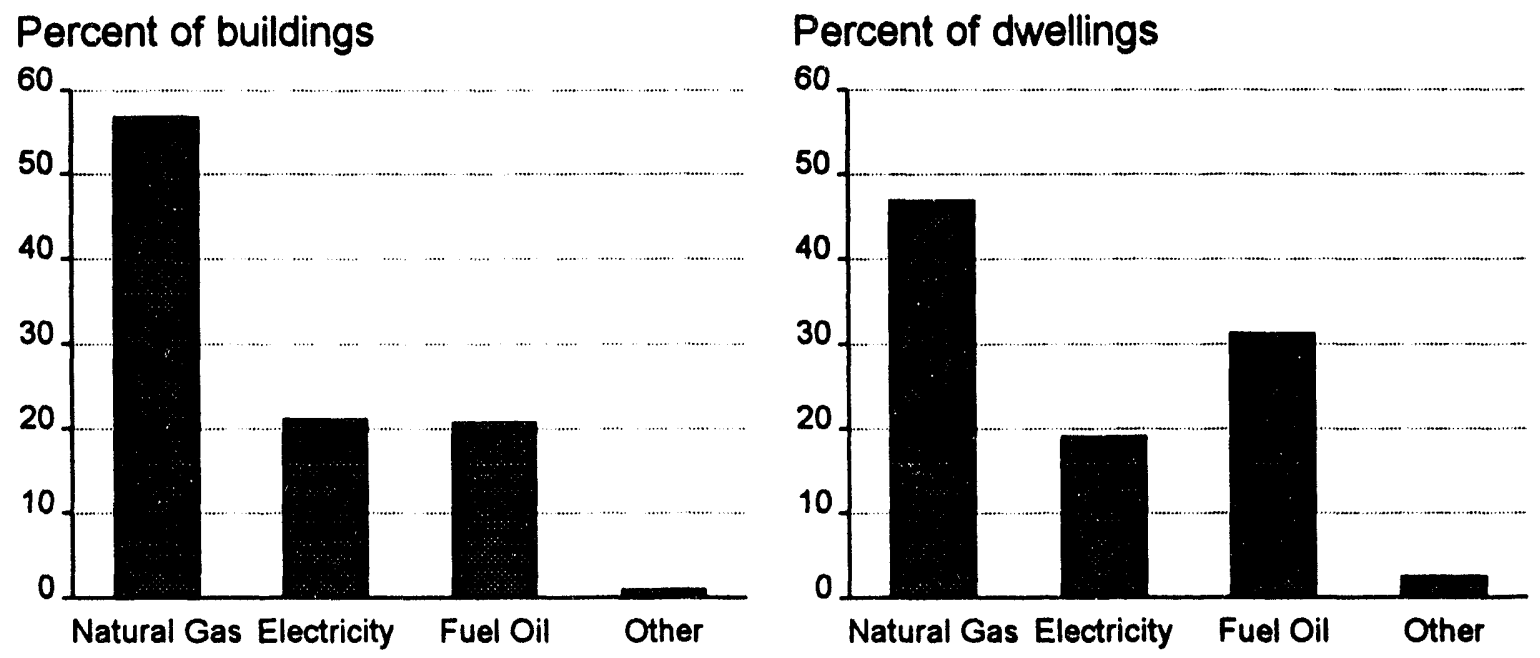

Figure 5 - Heating fuel for sample of buildings and residences weatherized in PY 1989.

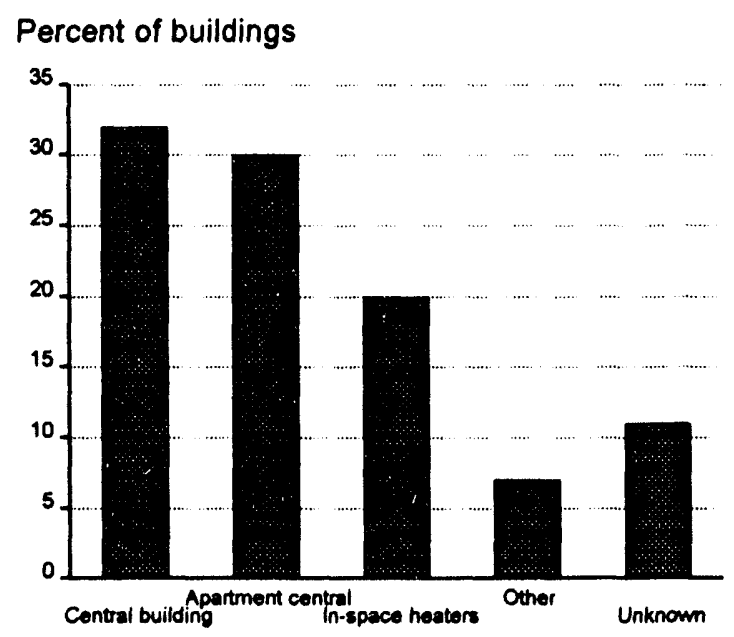

Figure 6 - Building space heating system type.

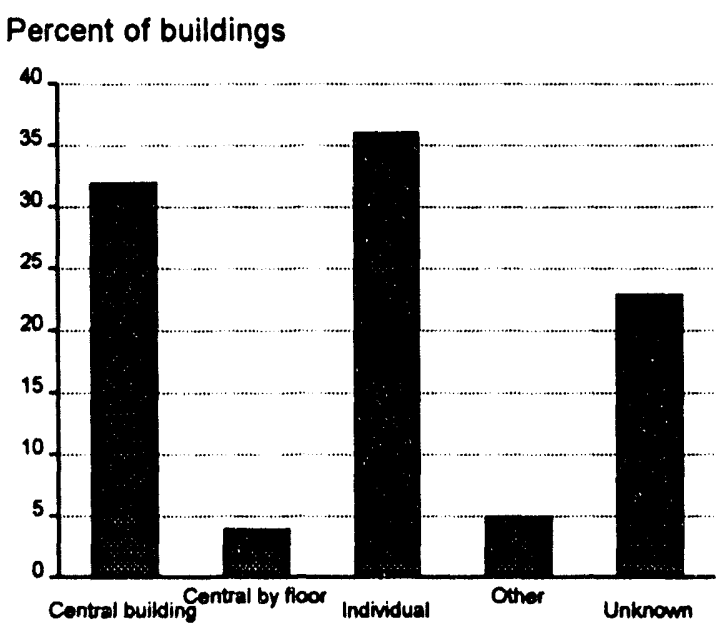

Figure 7 - Building water heating system type. 


\subsection{INCOME, ELDERLY, AND HANDICAPPED}

The percentages of people in different income categories for the weatherized dwellings are shown in Fig. 8. Dwellings with an income of less than $\$ 5,000$ per year accounted for $31 \%$ of all households in this sample, while only $8 \%$ had incomes over 15,000 per year. This distribution differs from that found for single-family and small multifamily dwellings (Brown et al 1993) in that no in-

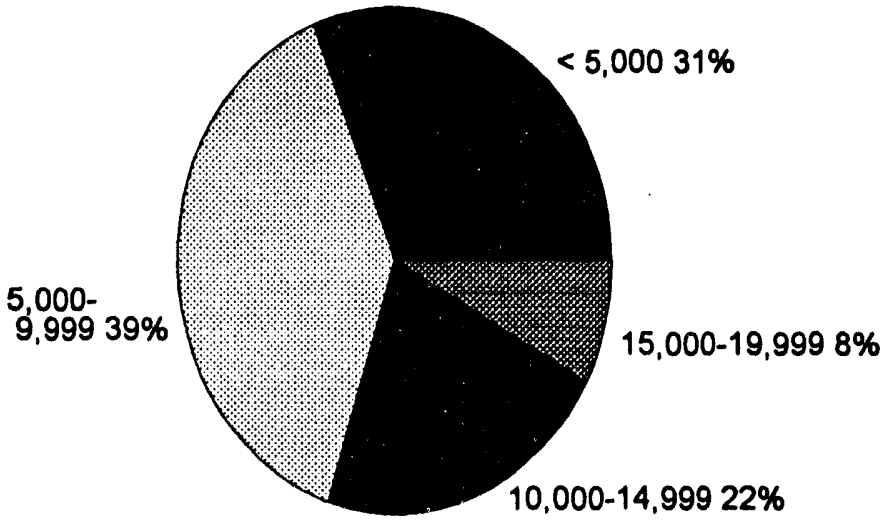

Figure 8 - Distribution of income categories for weatherized dwellings. comes of $\$ 20,000$ or more were present, but a higher percentage of incomes above $\$ 10,000$ was found. These higher incomes may be due to the fact that many dwellings are located in New York City, where higher incomes provide less purchasing power.

Elderly and handicapped people were known to be present in many of the households. The data indicate that 7,000-8,000 people lived in the buildings in the sample which were weatherized, while about 3,000 people lived in the weatherized dwellings. Elderly people were known to comprise $20 \%$ of the people living in the weatherized dwellings, and about $15 \%$ of the people in these dwellings were known to be handicapped. The elderly were present in $45 \%$ of the buildings that were served, and handicapped individuals were present in $36 \%$ of the buildings.

\subsection{GEOGRAPHIC DISTRIBUTION}

The distribution of buildings and dwelling units in the sample is shown by geographic zone in Fig. 9. The distribution shows the dominance of the moderate climate zone and the small number of dwellings from the hot zone. With New York in the moderate zone accounting for over half of all dwellings weatherized, the dominance of the moderate zone is to be expected. 

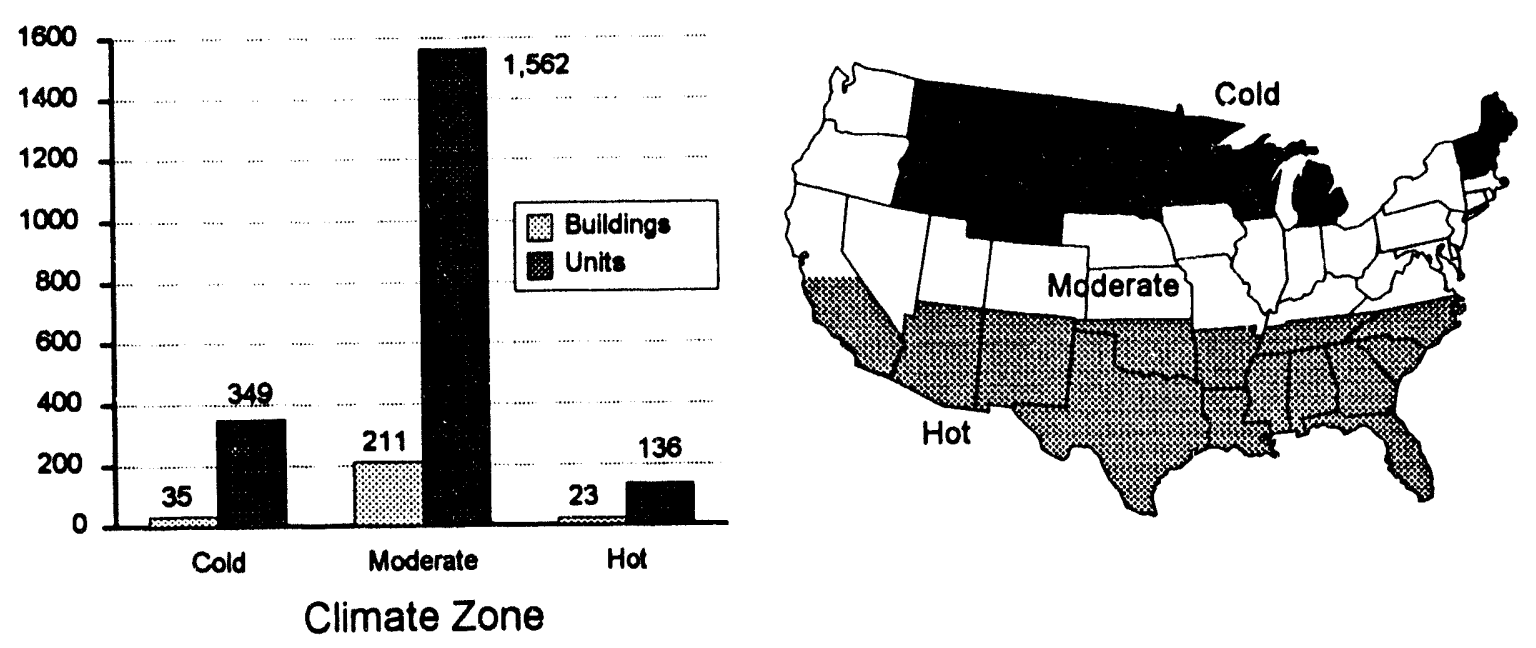

Figure 9 - Geographic distribution of sample of buildings and dwellings weatherized in PY 1989.

\subsection{MEASURES INSTALLED}

The measures installed under the Program in multifamily buildings cover a wide range, with significant numbers of buildings and units receiving general caulking, storm/thermal windows, and low-flow showerheads. The measures installed were cietermined from responses to the building-specific questionnaire sent to agencies (Appendix B). The measures fell into nine general categories, similar to the Single-Family Study (Brown et al 1993) categories:

- Air Leakage Control

- Water Heating System

- Space Cooling System

- Windows and Doors
- Insulation

- Space Heating System

- Ventilation System

- Structural Repairs

- Other Health and Safety Repairs or Improvements

For each of these nine general categories, specific information was requested for specific measures or retrofits that applied under each category. The numbers of buildings and units receiving each specific type of measure or retrofit for our sample of 269 buildings and about 2000 units is shown in Table 2, where BUILDING indicates the number of buildings and UNIT indicates the number of dwelling units receiving each type of measure. (Appendix B, Part C provides the data structure for the data in Table 2, so refer there for additional information and clarification, if needed.) 


\begin{tabular}{|c|c|c|c|c|}
\hline MEASURE & BUILDING & $\%$ & UNIT & $\%$ \\
\hline Air Leakage Control & 243 & $90 \%$ & 1275 & $62 \%$ \\
\hline General Caulking and Weatherstripping & 242 & $90 \%$ & $\begin{array}{c}1262 \\
185\end{array}$ & $62 \%$ \\
\hline $\begin{array}{l}\text { Air Sealing, with blower door testing } \\
\text { Air Sealing. with hut blower door testing }\end{array}$ & $\begin{array}{l}24 \\
37\end{array}$ & $9 \%$ & $\begin{array}{l}185 \\
103\end{array}$ & $\begin{array}{l}9 \% \\
9 \%\end{array}$ \\
\hline $\begin{array}{l}\text { Air Sealing, without blower door testing } \\
\text { Air Distribution System }\end{array}$ & $\begin{array}{c}37 \\
8\end{array}$ & $\begin{array}{l}14 \% \\
3 \%\end{array}$ & $\begin{array}{l}193 \\
22\end{array}$ & $1 \%$ \\
\hline $\begin{array}{l}\text { Other Infiltration Reduction (not including } \\
\text { windows) }\end{array}$ & 52 & $19 \%$ & 278 & $14 \%$ \\
\hline Insulation & 75 & $28 \%$ & 527 & $26 \%$ \\
\hline Attic Insulation (installed for the first time) & 33 & $12 \%$ & 177 & $9 \%$ \\
\hline $\begin{array}{l}\text { Attic Insulation (added to existing } \\
\text { insulation) }\end{array}$ & 30 & $11 \%$ & 318 & $16 \%$ \\
\hline Wall Insulation (normal technique) & 13 & $5 \%$ & 65 & $3 \%$ \\
\hline Wall Insulation (high-density technique) & 1 & $0 \%$ & 32 & $2 \%$ \\
\hline Floor Insulation & 6 & $2 \%$ & 28 & $1 \%$ \\
\hline Rim or Band Joist Insulation & 24 & $9 \%$ & 130 & $6 \%$ \\
\hline Other Envelope Insulation & 11 & $4 \%$ & 61 & $3 \%$ \\
\hline Water Heating System & 128 & $48 \%$ & 1168 & $57 \%$ \\
\hline Water Heater Tank Insulation & 46 & $17 \%$ & 215 & $11 \%$ \\
\hline $\begin{array}{l}\text { Entire Water Heating Unit Replacement } \\
\text { Central System Controls Improvements }\end{array}$ & 3 & $1 \%$ & 8 & $0 \%$ \\
\hline Pipe Insulation & 69 & $26 \%$ & 427 & $21 \%$ \\
\hline $\begin{array}{l}\text { Low Flow Shower Heads or Faucet } \\
\text { Aerators }\end{array}$ & 73 & $27 \%$ & 872 & $43 \%$ \\
\hline Temperature Reduction & 17 & $6 \%$ & 115 & $6 \%$ \\
\hline Other Water Heater Measures or Repairs & 2 & $1 \%$ & 13 & $1 \%$ \\
\hline Space Heating System & 85 & $32 \%$ & 1031 & $50 \%$ \\
\hline Clean and Tune-up & 25 & $9 \%$ & 547 & $27 \%$ \\
\hline Thermostat or Other Controls Retrofit & 45 & $17 \%$ & 256 & $13 \%$ \\
\hline $\begin{array}{l}\text { Entire Heating Unit } \\
\text { Replacement/Modification }\end{array}$ & 2 & $1 \%$ & 52 & $3 \%$ \\
\hline Repairs & 4 & $1 \%$ & 187 & $9 \%$ \\
\hline $\begin{array}{l}\text { Distribution System Retrofit (e.g., steam } \\
\text { balancing) }\end{array}$ & 9 & $3 \%$ & 389 & $19 \%$ \\
\hline Heating System Component Retrofits & 5 & $2 \%$ & 93 & $5 \%$ \\
\hline Safety Problem Fixed & 6 & $2 \%$ & 29 & $1 \%$ \\
\hline Other Heating System Modifications & 4 & $1 \%$ & 10 & $0 \%$ \\
\hline Space Cooling System & 25 & $9 \%$ & 132 & $6 \%$ \\
\hline $\begin{array}{l}\text { Tune-up (e.g., cleaning, controls } \\
\text { adjustment, filter replaced) }\end{array}$ & 17 & $6 \%$ & 102 & $5 \%$ \\
\hline $\begin{array}{l}\text { Entire Air-Conditioning System } \\
\text { Replacement }\end{array}$ & 1 & $0 \%$ & 1 & $0 \%$ \\
\hline $\begin{array}{l}\text { Fans Installed or Replaced } \\
\text { Thermostat or Other Controls Retrofit }\end{array}$ & 15 & $6 \%$ & 76 & $4 \%$ \\
\hline $\begin{array}{l}\text { Distribution System Retrofit (e.g., duct } \\
\text { sealing/balancing) } \\
\text { Other Cooling System Modifications }\end{array}$ & 1 & $0 \%$ & 1 & $0 \%$ \\
\hline
\end{tabular}




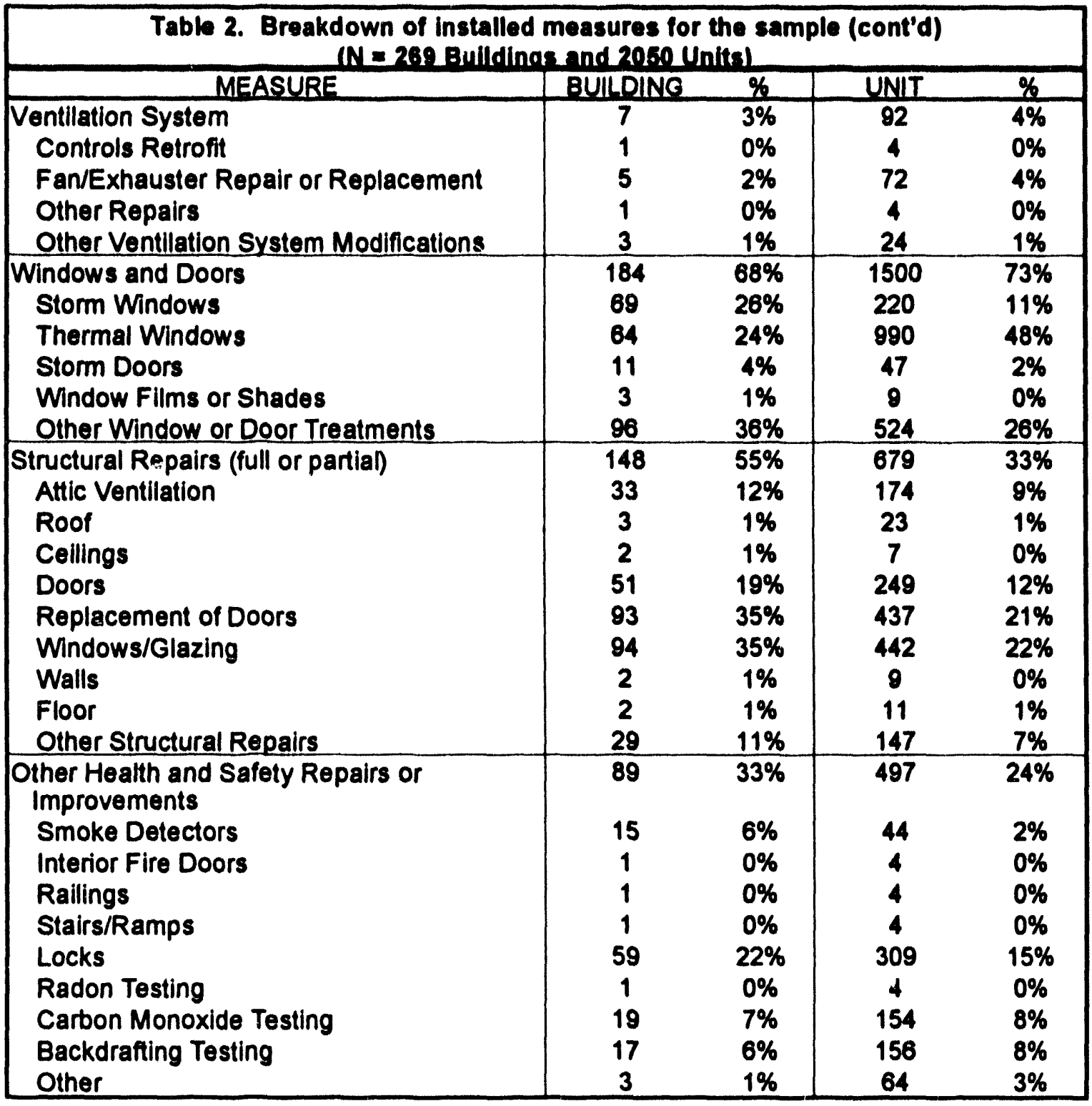

Measures were handled about equally for "in-house crew only" (about 100 buildings), "contractor only" (about 100 buildings), and "mixed crew and contractor" installations (about 70 buildings, but missing data make the exact number for each of these cases somewhat uncertain). Air leakage control measures were much more likely to be installed by in-house crews. Air sealing with blower door testing was especially likely to be performed in-house, but air distribution sealing had 20 units done by contractor and only 2 units done in-house. Water heater tank insulation was installed about twice as often by in-house crews. 
Four times as many heating system tuneups were performed by contractors compared to in-house crews, and almost all heating system thermostat or controls retrofits were installed by in-house crews. Heating system distribution retrofits were, again, mostly done in-house. Cooling system work was performed mostly in-house.

Storm windows were installed about equally by in-house and contractor crews, but thermal windows were 15 times more likely to be installed by contractors. Repairs and safety/health improvements were performed by both groups, with some shifting back and forth on which group did more. Overall, the low numbers of installations for some measures indicate caution for interpreting too much from these values.

\subsection{MEASURE SELECTION, DIAGNOSTICS, AND QUALITY CONTROL}

Selection of measures was accomplished primarily by use of priority lists $(85 \%$ of buildings and dwellings), while more advanced procedures were used in the remaining buildings. General rules were also the primary methods used for determining measures for space-heating and domestic hot water systems.

Blower door diagnostic procedures of some type were used in $25-30 \%$ of the buildings and dwellings. Heating system efficiency testing was used in about $15 \%$ of the larger buildings (almost $50 \%$ of the total dwellings). Almost all buildings had some type of visual quality control inspection for envelope measures, and the data suggest that most buildings whi h had heating system efficiency testing performed for diagnostic purposes also had efficiei: $:$ tests performed after the weatherization was completed. Table 3 provides a breakdown of data on measure selection methods, use of diagnostics, and quality control procedures for BUILDING and UNIT values as used in Table 2. (Appendix B, Part D provides the data structure for the data in Table 3, so refer there for clarification, if needed.)

\subsection{MEASURE COSTS}

Costs on measures were collected in several categories. The materials costs were collected for both in-house crew materials and contractor materials. However, some agencies provided "Other" material costs, and we also had to include those. The costs for in-house labor were requested, and the total contractor costs were requested. In some cases both contractors and in-house crews performed different work on the same building, and this work is referred to as "mixed crews." Agencies were not always able to provide the cost data, and sometimes the cost data were inconsistent (possibly indicating that the data request was not understood clearly). However, overall the cost data appear to provide a 


\begin{tabular}{|c|c|c|c|c|}
\hline & BUILDING & $\%$ & UNIT & $\%$ \\
\hline $\begin{array}{l}\text { Measure Selection } \\
\text { Envelope } \\
\text { Priority list } \\
\text { Scoring approach } \\
\text { Cost-Beneff }\end{array}$ & $\begin{array}{c}229 \\
11 \\
48 \\
\end{array}$ & $\begin{array}{c}85 \% \\
4 \% \\
18 \%\end{array}$ & $\begin{array}{c}1807 \\
209 \\
308\end{array}$ & $\begin{array}{l}88 \% \\
10 \% \\
15 \%\end{array}$ \\
\hline $\begin{array}{l}\text { Heating-Cooling - Ventilation System } \\
\text { Characteristics } \\
\text { Scoring } \\
\text { Cos'-Beneft } \\
\end{array}$ & $\begin{array}{c}53 \\
7 \\
20 \\
\end{array}$ & $\begin{array}{c}20 \% \\
3 \% \\
7 \% \\
\end{array}$ & $\begin{array}{l}368 \\
151 \\
182 \\
\end{array}$ & $\begin{array}{c}18 \% \\
7 \% \\
9 \%\end{array}$ \\
\hline $\begin{array}{l}\text { Domestic Hot Water System } \\
\text { Characteristics } \\
\text { Scoring } \\
\text { Cost-Eenefit } \\
\end{array}$ & $\begin{array}{c}88 \\
3 \\
38\end{array}$ & $\begin{array}{c}33 \% \\
1 \% \\
14 \%\end{array}$ & $\begin{array}{c}471 \\
97 \\
200\end{array}$ & $\begin{array}{c}23 \% \\
5 \% \\
10 \%\end{array}$ \\
\hline $\begin{array}{l}\text { General Considerations } \\
\text { Envelope. HVAC, and DHW measures } \\
\text { selected together } \\
\text { Pre-screening } \\
\text { Consultant } \\
\text { Other procedure } \\
\end{array}$ & $\begin{array}{c}110 \\
19 \\
7 \\
115\end{array}$ & $\begin{array}{l}41 \% \\
7 \% \\
3 \% \\
43 \% \\
\end{array}$ & $\begin{array}{r}1245 \\
83 \\
14 \\
9 \\
\end{array}$ & $\begin{array}{l}61 \% \\
4 \% \\
1 \% \\
0 \%\end{array}$ \\
\hline $\begin{array}{l}\text { Diagnostics } \\
\text { Blower-door find } \\
\text { Blower-door measure } \\
\text { Blower-door guide } \\
\text { Distribution balance } \\
\text { Distribution seal } \\
\text { Infrared } \\
\text { IAQ testing } \\
\text { Efficiency testing } \\
\text { Combustion safety } \\
\text { Other } \\
\end{array}$ & $\begin{array}{c}39 \\
27 \\
4 \\
1 \\
0 \\
3 \\
11 \\
37 \\
36 \\
15\end{array}$ & $\begin{array}{l}14 \% \\
10 \% \\
1 \% \\
0 \% \\
0 \% \\
1 \% \\
4 \% \\
14 \% \\
13 \% \\
6 \%\end{array}$ & $\begin{array}{c}313 \\
259 \\
68 \\
6 \\
0 \\
49 \\
113 \\
942 \\
258 \\
63 \\
\end{array}$ & $\begin{array}{c}15 \% \\
13 \% \\
3 \% \\
0 \% \\
0 \% \\
2 \% \\
6 \% \\
46 \% \\
13 \% \\
3 \% \\
\end{array}$ \\
\hline $\begin{array}{l}\text { Quality Control } \\
\text { Visual - envelope } \\
\text { Blower-door } \\
\text { Infrared } \\
\text { Visual - heating } \\
\text { Efficiency testing } \\
\text { Other } \\
\end{array}$ & $\begin{array}{c}264 \\
18 \\
4 \\
22 \\
40 \\
0\end{array}$ & $\begin{array}{c}98 \% \\
7 \% \\
1 \% \\
8 \% \\
15 \% \\
0 \%\end{array}$ & $\begin{array}{c}2041 \\
98 \\
52 \\
166 \\
784 \\
0\end{array}$ & $\begin{array}{c}100 \% \\
5 \% \\
3 \% \\
8 \% \\
38 \% \\
0 \%\end{array}$ \\
\hline
\end{tabular}

\begin{tabular}{|l|c|c|c|c|}
\hline \multicolumn{5}{|c|}{ Table 4. Materials costs per building for the sample (\$) } \\
\hline & MEAN & SUM & MEDIAN & \# BUILDINGS \\
\hline Whole Building & 7200 & 800,000 & 2000 & 111 \\
\hline Partial Building & 800 & 130,000 & 380 & 158 \\
\hline
\end{tabular}


fairly reasonable picture of the costs of these measures for multifamily buildings, if care is taken in calculating the desired information.

Material costs for buildings are calculated for both whole-building and partial-building weatherization (Table 4). The whole building category accounts for about $\$ 800,000$, the major portion of materials costs for our sample. The partial building category accounts for about \$130,000. The materials funds invested per building in whole-building weatherizations are much higher than those invested for partial-building weatherizations, as many more units were weatherized per building in whole-building weatherizations (see Table 1).

The distribution of materials costs reported by the agencies is shown by major measure category in Fig. 10, which clearly shows the dominance of expenditures on windows and doors ( $80 \%$ of the total). Costs for windows are most of the total for the windows and doors category. The average cost of installed measures, when they are installed, is shown in Table $S$ for whole-building and partial-building weatherizations, where reported data were available. The funds invested per unit for whole-building work were higher than funds invested per unit for partial-building work (\$561 vs \$417), since the costs for windows in wholebuilding work was a major difference. Whole-building work also included higher space heating system retrofit and replacement costs and higher ventilation system replacement costs.

Readers are cautioned to consider the number $(\mathrm{N})$ of units shown for each measure category listed in Table 5. Those entries with low numbers of units must be viewed with caution when considering whether the values represent the Program as a whole in PY 1989. The mean dollar values in Table 5 are based on using the entire number of units weatherized in a building as the divisor, so some mean values will appear low. For example, the entry for water heater replacement under whole-building work appears unreasonable. Apparently a water heater was replaced in only one unit each of a 15-unit and a 16-unit building. The average cost per unit in each building is very low, but the total cost for the building is $\$ 210$. Thus, the average cost per unit value can be misleading for some categories. Data were collected only at the building level and not at the unit level, so the exact equipment installed in each separate dwelling unit is not known. However, in general, this type of information was not available from the agencies.

Cost data breakouts for in-house, contractor, and mixed crews are shown in Table 6. These costs are, again, based on reported values, and some data discrepancies can exist because of missing data. The labor cost for mixed crews is found to be half of total costs, and this value may be higher than expected because of cases of missing data on contractor materials. These data indicate that costs for dwellings in larger multifamily buildings receive one-half to two thids the average irvestment received in single-family and small multifamily

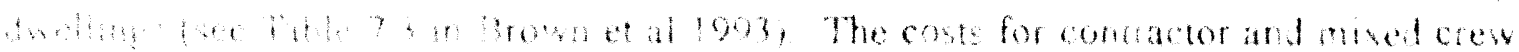




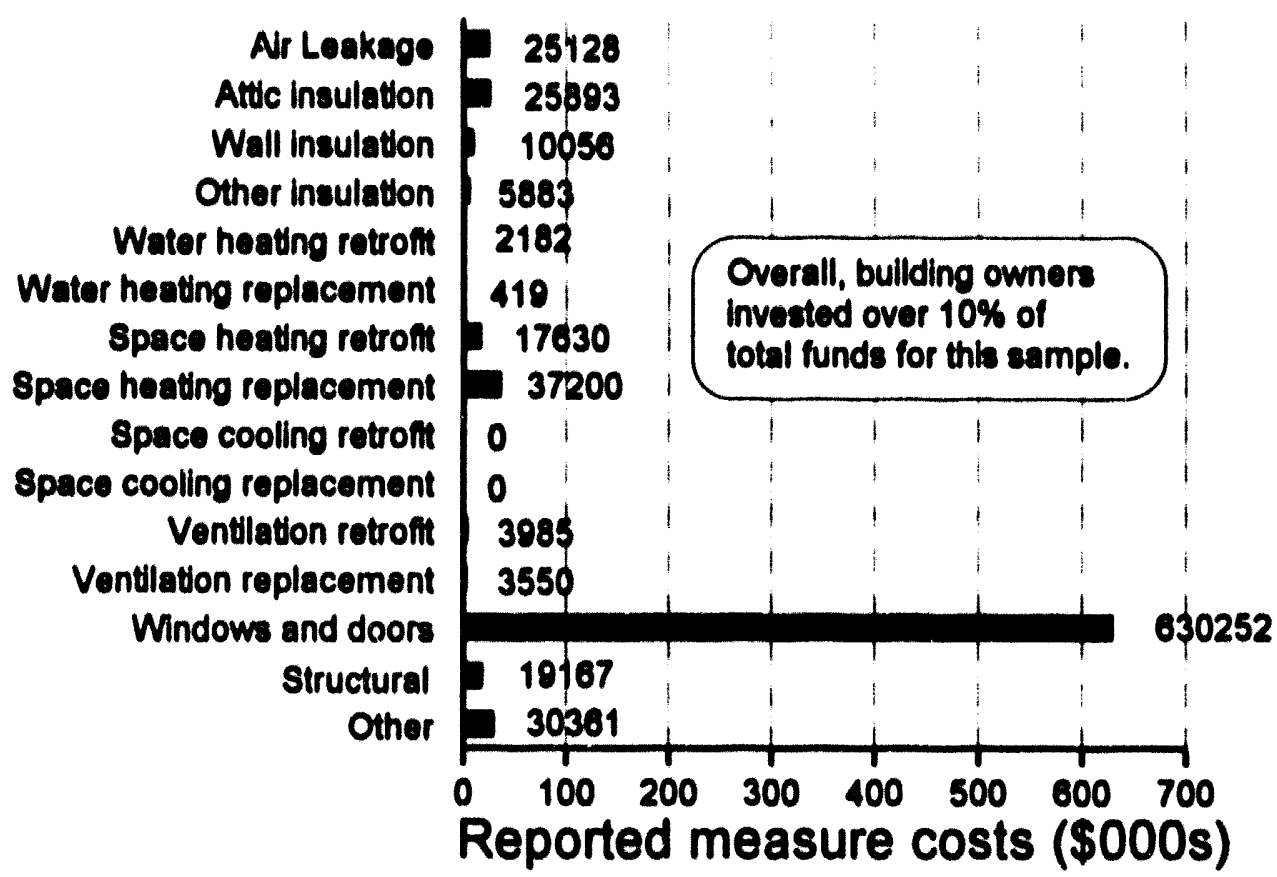

Figure 10 - Distribution of reported materials costs by measure.

Table 5. Breakdown of material costs for units where measure was installed

\begin{tabular}{|l|c|c|c|c|}
\hline \multirow{2}{*}{ MEASURE } & \multicolumn{2}{|c|}{ WHOLE BUILDING WORK } & PARTIAL BUILDING WORK \\
\cline { 2 - 5 } & $\mathbf{N}$ & Mean S & N & Mean S \\
\hline Air Leakage & 408 & 41 & 109 & 76 \\
Attic insulation & 383 & 59 & 28 & 118 \\
Wall insulation & 174 & 57 & 4 & 52 \\
Other insulation & 170 & 27 & 31 & 44 \\
Water heating retroft & 117 & 17 & 22 & 9 \\
Water heating replacement & 31 & 14 & 0 & - \\
Space heating retrofit & 275 & 63 & 17 & 18 \\
Space heating replacement & 64 & 581 & 0 & - \\
Ventilation retrofit & 155 & 23 & 11 & 45 \\
Ventilation replacement & 98 & 1244 & 1 & 117 \\
Windows and doors & 942 & 555 & 246 & 437 \\
Structural & 211 & 76 & 43 & 73 \\
Safety and Health & 319 & 70 & 108 & 75 \\
TOTAL for Reported Data & 1421 & 561 & 319 & 417 \\
\hline Total Observations & 1608 & & 439 & \\
\hline
\end{tabular}




\begin{tabular}{|l|c|c|}
\hline \multicolumn{2}{|c|}{ Table 6. Costs per dwelling for in-house, contractor, and mixed crews } \\
\hline \multicolumn{1}{|c|}{ Category } & $\begin{array}{c}\text { Average total installed cost } \\
\text { (\$/dwelling) }\end{array}$ & $\begin{array}{c}\text { Average labor cost } \\
\text { (\$/dwelling) }\end{array}$ \\
\hline In-house crew only & $450^{\circ}$ & 140 \\
\hline Contractor only & $780^{\circ}$ & $180^{\circ}$ \\
\hline Mixed (both crew and contractor) & $720^{\circ}$ & $360^{\circ}$ \\
\hline $\begin{array}{l}\text { includes materials and labor } \\
\text { includes materials, labor, profit, and installation-related overhead } \\
\text { includes labor, profit, and installation-related overhead }\end{array}$ \\
\hline
\end{tabular}

installations are expected to be higher than in-house crew installations, because overhead and profit expenses are not included for the in-house values. The contractor and mixed crew values are higher than the in-house values by about $\$ 300$, due to the overhead and profit difference and to contractors installing more costly thermal windows (primary cause), space heating system replacements, and ventilation system replacements.

Total material, labor, and contractor costs are calculated for all buildings to be about $\$ 600 /$ unit, as reported. There are seven severe cases of buildings where over $\$ 2500$ per unit was invested, outside the expected range of reasonable costs. However, the data for New York may be lower than representative for that State, based on examination of our supplemental New York data (recall that New York accounts for over half of all units for PY 1989). Overall, these factors suggest that the average cost per unit weatherized, without overhead and management costs included, is about $\$ 600$.

The estimated overhead and management cost per unit weatherized for the Program has been estimated at about \$500/unit in the Single-Family Study (Brown et al 1993). The data obtained in the Single-Family Study on overhead and management costs were incomplete and difficult to analyze because of obvious inaccuracies. The value of $\$ 500$ was estimated based on other data sources and the limited usable data obtained for that study.

A downward adjustment of this $\$ 500$ value for larger multifamily buildings is appropriate, since the investment per dwelling was about half the installation cost for single-family and small multifamily dwellings (Brown et al 1993). A straight ratio of these values would lead to a value of \$250-350 per dwelling, but a straight ratio is probably not completely correct either. A value of $\$ 400$ per dwelling appears reasonable, although better determination of this value based on empirical data would be helpful. Using the average overhead and management value of $\$ 400 /$ unit, total cost for multifamily weatherization in PY 1989 becomes $\$ 1000 /$ unit $(\$ 600+\$ 400)$. 
The overall cost magnitude of the program, with about 20,000 multifamily dwellings weatherized in PY 1989 at $\$ 1000 /$ unit, is then about $\$ 20$ million out of total expenditures for the Program of about $\$ 300$ million (about $7 \%$ ). 


\section{NONENERGY PROGRAM IMPACTS}

Work conducted under the Program leads to significant nonenergy impacts and benefits. The Single-Family Study (Brown et al 1993) provides a helpful description of these benefits, and the value of these benefits is monetized, where possible, in that study. Five major areas of benefits for the Program are: More affordable housing; Improved comfort, health, and safety; Easing of household budget limitations; Increased employment and beneficial economic impacts; and Environmental externality benefits.

Program efforts in larger multifamily buildings have benefits parallel to those for singlefamily and small multifamily dwellings. Affordable housing is aided by structural and safety improvements, which help increase property values and longevity of buildings. Owner investments, in many cases, indicate their understanding of these benefits. Safety improvements are important, as many buildings are located in large cities. Structural repairs were made in $55 \%$ of all buildings, while safety and health improvements were made in $33 \%$ of all buildings.

Employment and economic impacts of the $\$ 20$ million invested in larger multifamily buildings is not small. The Single-Family Study estimates that 52 job years are created for each $\$ 1$ million invested by the Program. Thus, \$20 million invested for larger multifamily buildings accounts for about 1,000 jobs in PY 1989. Revenue generated from resulting taxes for this employment has a direct benefit to governments.

Environmental benefits can also be important, The $\$ 20$ million invested in larger multifamily buildings is estimated to cause reduced emissions of over 3,000 metric tons of carbon per year. Other reduced emissions of $\mathrm{SO}_{2}$ and $\mathrm{NO}_{\mathrm{x}}$ also provide benefits. Overall, the nonenergy benefits of the Program efforts are important, and these benefits are an important objective of the Program.

Because of the lack of energy and energy cost data, the nonenergy benefits are not monetized for this study. Those interested in a further discussion of these nonenergy benefits should consult Brown et al (1993). 


\section{OVERALL RESULTS}

This study has shown that the Program activities in larger multifamily buildings in PY 1989 represent about $9 \%$ of all dwellings weatherized and $7 \%$ of total costs. However, $15 \%$ of all eligible households not in public housing and $33 \%$ of all eligible renter-occupied residences not in public housing are in the larger multifamily buildings (see Introduction). Thus, Program efforts in these buildings occur at a lower level than proportional with the percentage of the eligible population in these buildings.

\subsection{GEOGRAPHIC DISTRIBUTION OF MULTIFAMILY DWELLINGS}

Based on responses from the Grantees and the local agencies and on interactions with States and agencies regarding requested responses, a composite estimate of the geographic distribution of dwellings weatherized under the Program in PY 1989 is provided in Figure 11. High levels of multifamily activity were found from the Northeast extending to the upper mid-Atlantic region. Reasonably high levels of activity were found in the Midwest, pockets of activity in the West, and almost no activity in the South outside the upper mid-Atlantic area. The distribution of these units aggregated to the three climate zones shown in Fig. 9 is given in Fig. 12. Just as with the sample of buildings obtained from individual agencies, the moderate zone is dominant and few units are in the hot zone.

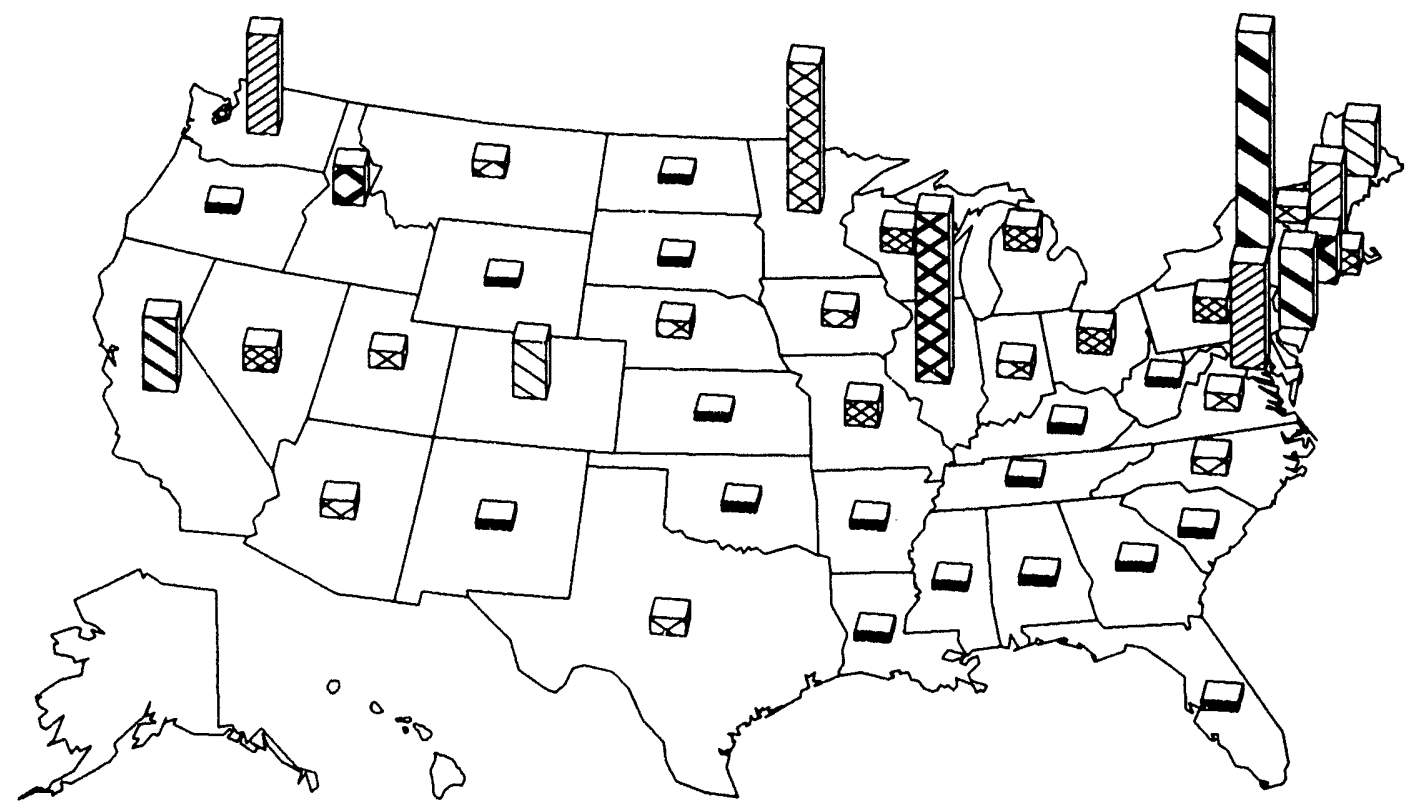

Figure 11 - Geographical distribution of 20,000 weatherized multifamily dwellings for PY 1989.

The very short bars indicate no dwellings were weatherized, and the next tallest bar represents a few units.

The tall bar for New York represents 11,500 units (over half of the total but scaled here to allow the scale of the others to be seen), and the bars for Illinois and Minnesota represent about 1,500 units served. 


\subsection{ADVANCED PROGRAMS}

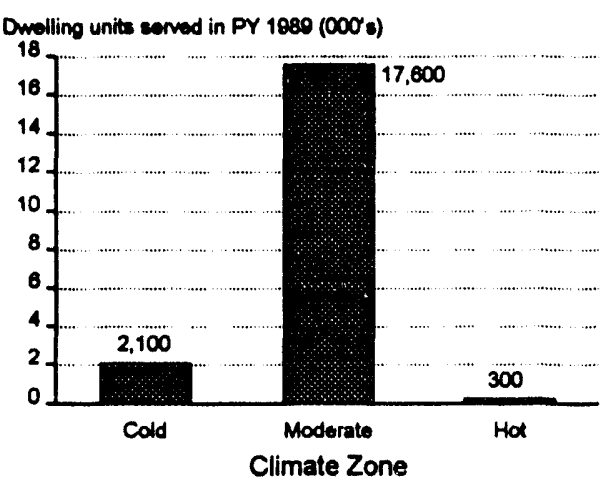

Figure 12 - Distribution of 20,000 dwellings by climate zone.
Investments by building owners are found in only a few States, and in our sample of buildings, both Massachusetts and New York obtained about 25\% of their total funds invested in weatherization from owners. Massachusetts and New York accounted for $97 \%$ of all owner investments obtained in the sample. However, for the country the major source of these investments is New York, because New York represents half of all units served. Thus, for the country, about half of all units weatherized in PY 1989 received owner investments for improving the energy efficiency of the buildings. The additional data for New York that were not included

directly in the sample indicate that owner investments can be as high as $35 \%$ of total investment.

New York and Massachusetts provide important evidence that the impact of the Program can be expanded by leveraging investments by owners in some of these buildings. New York also provides a major increase to available funds, since owner investments are obtained for most buildings and such a large percentage of total units weatherized in the country is done in New York. New York also has directed significant efforts at developing good energy audit procedures for larger multifamily buildings and at improving consistency of results across buildings. (The EA-QUIP energy audit program for multifamily buildings, which prioritizes measures based on cost effectiveness, can be obtained from New York.) The transfer of the knowledge available in States where more multifamily work is performed thus becomes an issue for the Program, as other States might enjoy important benefits if they could adopt the most appropriate practices used by States like New York or Massachusetts. However, despite important improvements achieved to date, weatherization personnel from New York assert that much more still needs to be learned about the performance of measures in larger multifamily buildings. New York is currently working to plan additional research in this area.

\subsection{DISCUSSION OF THE LOW LEVEL OF MULTIFAMILY ACTIVITY}

There are many reasons for the low level of activity under the Program for multifamily buildings. Primarily, the buildings and building systems are often much different than those found in single family and small multifamily buildings, and the outreach activities needed to qualify whole buildings are often more extensive. When whole buildings cannot be 
qualified, the types of measures available to install at the dwelling-unit level are typically much more limited. Our data show that heating system replacement and other space heating retrofits were performed much more often under whole-building work. With more limited measures available, field personnel may have doubts about how useful and effective the measures are.

In addition to the reasons given above, there is the fundamental condition that many people who could be helped under the Program have not yet received services. Thus, qualified tenants in multifamily buildings may represent a large portion of the eligible population, but they are simply another segment of the population waiting to be served. Given the large unmet need, providers are more likely to serve the eligible population most similar to those they have historically served.

Since likely less than $14 \%$ of the eligible population has been served (Power and Brown 1993), and a large portion of the eligible population is in single-family and small multifamily houses, the inclination for agencies will be to continue to serve this large constituency. Service to multifamily buildings will depend on the Program funding available, factors that make qualification of buildings easier, and level of technical expertise achieved for dealing with these potentially more complex buildings. The level of service to these buildings may also depend on the level of attention applied to these buildings by the Program.

Improved information on the performance of different measures in multifamily buildings, together with efforts to transfer knowledge from more active States to less active States, could help increase the number of units served in these buildings under the Program. Increased use of owner investments could also be important in some locations, as the situation in New York and Massachusetts illustrates that increased benefits can be obtained for occupants while increasing building property value. Both owners and the Program invest, and both reap increased benefits from the partnership.

\subsection{DISCUSSION OF OTHER PROGRAMS}

The major compilation of energy savings results for multifamily buildings by Goldman et al (1988) indicates that savings of 10-30\% are typical for many multifamily buildings. They also found that installation of building shell measures, such as insulation and windows (which were typically installed in electric-heat buildings), led to building retrofit programs which are not cost effective. Conversely, they found that multifamily retrofit programs which emphasized changes to central heating systems tended to be very cost effective. Building shell measures were typically installed for buildings having electric heat, while heating system measures were installed in buildings heating with natural gas or fuel oil. 
Okumo (1991) found that windows were not generally cost effective in electric-heat buildings, while other building shell measures may have been cost effective.

Many program results are available from programs (not part of the DOE Weatherization Program) in Minneapolis ${ }^{1}$ and Chicago, ${ }^{2}$ where buildings use natural gas and fuel oil to heat, and typically many good candidate buildings are available for central heating system retrofits. High savings are often available from these central system retrofits, where simple payback periods of about two to three years are often achieved. Benefit/Cost ratios calculated with a $4.7 \%$ discount rate (assuming a 20 year measure lifetime) for these paybacks would typically be 5-8.

The programs mentioned above are typically funded entirely by building owners, sometimes with additional support from the city or from utilities. Thus, these programs face more stringent economic criteria which force the programs toward measures having higher economic returns. However, the economic criteria and objectives of DOE's Weatherization Program are different, and installation of additional measures beyond these high payback measures are often desirable.

One final program on multifamily buildings for discussion here is conducted by the Citizens Conservation Corporation (CCC) in Boston, often for public housing buildings. $\mathrm{CCC}$ has installed many types of retrofits in multifamily buildings over many years, including central heating system retrofits. Funding for $\mathrm{CCC}$ efforts has come through performance contracting arrangements, utility programs, and other sources. CCC has experience with both individual dwelling metering systems in buildings having central meters for heating fuel and individual dwelling automatic temperature control systems which allow good energy management practices to be used. Recently, CCC also began working on buildings where advanced window systems are being installed. The experience of CCC with their measures has not been documented publicly to date, but a project is currently funded under the DOE-HUD Initiative (a joint initiative between DOE and the U.S. Dept of Housing and Urban Development) to report on some of the experience of CCC with multifamily buildings.

1. For further information, contact Martha Hewett, Center for Energy and Urban Environment, 510 Ist Avenue North, Suite 510, Minneapolis, MN. 612/348-4835

2. For further information, contact John Katrakis, Center for Neighborhood Technology, 2125 W. North Avenue, Chicago, IL. 312/278-4800 


\section{CONCLUSIONS \& RECOMMENDATIONS}

The extent of weatherizations in larger multifamily buildings under DOE's Weatherization Program is estimated to be about 20,000 dwellings in Program Year 1989. This total includes dwellings weatherized both in private buildings and in public housing. Fairly extensive relationships with public housing have existed in some locations. These 20,000 dwellings represent about $9 \%$ of the total number of units weatherized under the Program that year, using the designated funding criteria. The total costs for the Program efforts in these buildings are about $7 \%$ of total national costs for the Program. The energy savings and cost effectiveness of the Program were not estimated, because energy use and energy cost data adequate for developing such estimates could not be obtained.

Researchers who wish to obtain and use energy use and cost data to estimate cost effectiveness of energy efficiency programs must consider the difficulty that occurs when such data move from on-line electronic form in a computer system to archival status. Data archival often occurs after 12 to 18 months. Archival increases data retrieval difficulty dramatically. Studies requiring such data that might be archived should develop data collection designs that recognize the potential problems with archived data.

The measures installed under the Program in these multifamily buildings during PY 1989 cover a wide range, but the materials costs for the measures are dominated by the costs for installation of windows. Understanding of potential improvements to the program will depend on developing a better understanding of the specific benefits of individual measures relative to cost effectiveness criteria pertinent to the Program. This understanding will also require developing a good knowledge of the nature of the multifamily building stock in different regions of the country. Direct interaction with local agencies is important to better understand measure benefits, because these organizations are trying to deal with these more complex buildings while having little empirical data to determine the most appropriate measures to meet the objectives of the Program.

Well known programs dealing with multifamily buildings in Minneapolis and Chicago have typically had more stringent economic criteria driving measure selection, and new results are needed to help determine the measures appropriate to the Program's economic criteria. Overall, better understanding of "good" retrofit packages applicable to the Program (probably developed by region) appears needed.

Considering the importance of better information on measure performance and recent changes in States with advanced programs, specific recommendations are:

1. Begin initial case study evaluations of specific buildings and the measures installed in those multifamily buildings. A case study of one large multifamily 
building provides results for many dwellings that are specific to a State or region. The initial case studies should be conducted to better understand the current state-of-the-art in multifamily weatherization under the Program. These case studies should be selected from cities in States with significant levels of multifamily activity, such as New York, Illinois, Minnesota, and Washington.

2. The reporting of these the initial case studies should include a summary on the benefits of specific measures, groups of measures, field procedures, or management procedures found in the case studies. This summary should also include recommendations regarding measures or procedures that deserve further refinement or assessment.

3. The Program should change data reporting requirements for Grantees to include specification of the amount of work accomplished in larger multifamily buildings. This change is important for highlighting the importance and also the different nature of this sector. For both small and large multifamily, Grantees should report the number of multifamily residences that were not treated as part of the whole building.

4. The impact of partial-building work on cost effectiveness should be studied at some time in the future. Many States have building stock where only individual apartments can be retrofitted under rules of the Program, and the cost effectiveness of this partial retrofit work must be understood better to determine if it should be continued.

5. Considerable expertise with multifamily buildings exists in some States. Transfer of this knowledge to other States that conduct multifamily work should be planned as the results of the case study work begin to be reviewed.

6. In addition to the knowledge gained from work conducted under the Program, the work of other organizations performing work in multifamily buildings should be considered relative to future refinement of procedures or measures used under the Program. For example, the work in Minneapolis and Chicago, cited in section 6.4 of this report, should be recalled when reviewing the case study results. Also, the work of Citizens Conservation Corporation, in Boston, should be examined, if access can be gained to their results.

7. Program procedures should be changed to effectively capture the energy savings to be found from common area or "house" lighting in these multifamily buildings. The savings from these lighting retrofits are important, and crews should attempt to achieve these savings while they are in a building, if the whole building is included in the work. 


\section{REFERENCES}

Berry, L. G., M. A. Brown, D. L. White, and T. Wright, 1991. Experimental Plan for the Single-Family Study, ORNL/TM-11668/V3, Oak Ridge, Tenn.: Oak Ridge National Laboratory.

Brown, M. A., L. G. Berry, R. A. Balzer, and E. Faby, 1993. National Impacts of the Weatherization Assistance Program in Single-Family and Small Multifamily Dwellings, ORNL/CON-326, Oak Ridge, Tenn.: Oak Ridge National Laboratory.

Beschen, D. A. and M. A. Brown, 1990. Evaluation Plan for the Weatherization Assistance Program, ORNL/TM-1 1668/V1, Oak Ridge, Tenn.: Oak Ridge National Laboratory.

The Economic Opportunity Research Institute, Inc., 1986. Low Income Energy Programs at Mid-Decade: Limits and Opportunities, Arlington, Virg.: The Economic Opportunity Research Institute, Inc.

EIA (Energy Information Admin. of the U.S. Dept. of Energy), 1986. Residential Energy Consumption Survey: 1984, public use data tape, currently available as: Residential Energy Consumption Survey: 1984 and Residential Transportation Energy Consumption Survey, 1985, public use data tape, NTIS PB87-186540/HAA

EIA 1990. Residential Energy Consumption Survey, 1987 (ASCII) (for microcomputers), computer diskettes, NTIS PB90-505115.

EIA 1993. Household Energy Consumption and Expenditures, 1990, DOE/EIA-0321(90).

Fels, M. F. 1986. "PRISM: An Introduction," Energy and Buildings, V 9(1 \& 2).

Goldman, C. A., K. M. Greely, and J. P. Harris, 1988. "An Updated Compilation of Measured Energy Savings in Retrofitted Multifamily Buildings," Proceedings of the 1988 ACEEE Summer Study on Energy Efficiency in Buildings, V 2, 2.75-2.88, Washington: American Council for an Energy Efficient Economy.

Mihlmester, P. E. et al, 1991. Characterization of the Weatherization Assistance Program Network, ORNL/CON-324, Oak Ridge, Tenn.: Oak Ridge National Laboratory.

Okumo, D. L., 1991. The Multifamily Conservation Program: Evaluation of Electricity Savings and Costs, Seattle: Seattle City Light.

Power, M. et al, 1992. Scope of the Weatherization Assistance Program: The Weatherized Population and the Resource Base, ORNL/CON-325, Oak Ridge, Tenn.: Oak Ridge National Laboratory.

Power, M., and M. Brown, 1993. "The Reach of Low-Income Weatherization Assistance," Home Energy, $\mathrm{V}$ 10(3).

Synertech, 1991. An Evaluation of the New York State Weatherization Assistance Program, SYN TR 91-540R, Syracuse, NY: Synertech Systems Corporation, pp 5-57 to 5-60.

Ternes, M. P., W. P. Levins, and M. A. Brown, 1992. Experimental Plan for the Fuel-Oil Study, ORNL/TM-11668/V2, Oak Ridge, Tenn.: Oak Ridge National Laboratory.

Ternes, M. P., and W. P. Levins, 1994. Impacts of the Weatherization Assistance Program in Fule-Oil Heated Houses, ORNL/CON-327, Oak Ridge, Tenn.: Oak Ridge National Laboratory. 


\section{APPENDIX A}

\section{National Evaluation of the DOE Weatherization Assistance Program State Grantee Survey High-Density Multifamily Units}

\section{PURPOSE}

The National Evaluation of the Weatherization Assistance Program (WAP) is initiating a study of multifamily buildings with five or more units, called the High-Density Multifamily Study. The purpose of this study is to learn about the extent of WAP weatherization services to high-density multifamily buildings and how such services might be improved. High-density multifamily will be referred to with the acronym HDMF in this survey.

Current data available from the National Evaluation indicate that HDMF units account for $10 \%$ of the units weatherized across the country in Program Year (PY) 1989. The data also indicate weatherization activity for HDMF units occurred in 44 States in PY 1989. However, HDMF units comprise about $15 \%$ of the total eligible population, so these multifamily units appear to be underserved in PY 1989, and they have been served even less in the past.

The purpose of this survey is to elicit comments on the nature of weatherization services offered for HDMF buildings in your state. Several experts have indicated there are significant problems with offering weatherization services to HDMF buildings, so we are also interested in information on the nature of obstacles impacting potential services to HDMF buildings and any innovative approaches you may be using to overcome these obstacles.

Over the next 6 months, the U.S. Department of Energy (DOE) will be collecting information on HDMF buildings from a sample of local WAP agencies and utilities in several States. We will inform you when such information requests are made, and we may ask for your assistance. The enclosed Evaluation Plan provides an overview of the HDMF Study and the other four studies that comprise the National WAP Evaluation.

\section{INSTRUCTIONS}

There are 11 questions in this survey. Each question except questions 1 and 11 asks for a yes/no answer at the beginning. Please circle the YES or NO answer appropriate to each question. Written responses are also requested in many cases. Keep in mind for the written responses that extreme detail is not needed at this time. Thank you for your time and effort. 


$$
\text { A }-2
$$

\section{QUESTIONS}

1. Please estimate how many high-density multifamily (HDMF) dwelling units (not bulldings) were weatherized in your state in Program Year (PY) 1989, using funds that are regulated by DOE/WAP rules:

HDMF is $5+$ units per building total HDMF units

ESTIMATE THE NUMBER IF YOU TRACK MULTIFAMILY DIFFERENTLY.

IF NO HDMF UNITS WERE WEATHERIZED IN PY 1989, PLEASE EXPLAIN WHY.

2. Do you have any stated policy placing either a high or low priority on providing weatherization services to HDMF buildings or apartments in your State relative to other building types?

YES NO

IF YOU ANSWERED YES, PLEASE DESCRIBE THE HIGH OR LOW PRIORITY BELOW, OR ATTACH A COPY OF ANY WRITTEN STATEMENT OF THE PRIORITY. ALSO DESCRIBE WHY THE HIGH OR LOW PRIORITY IS NEEDED.

WAS THIS POLICY IN EFFECT IN PY $1989 ?$

YES NO

ARE ANY POLICIES REGARDING PRIORITIES FOR HDMF BUILDINGS UNDER CONSIDERATION AT THIS TIME?

IF YES, PLEASE DESCRIBE. 


$$
\text { A - } 3
$$

3. Has your State conducted any evaluation of benents, costs, or cost effectiveness of WAP services to HDMF bulldings in your State during the last 10 years?

YES NO

IF YOU ANSWERED YES, PLEASE ATTACH A COPY OF THE EVALUATION REPORT OR DESCRIBE BELOW HOW WE MAY OBTAIN A COPY.

4. Do you currently have a recommended measures list, a priority list of measures, or a special energy audit measure selection method specincally for HDMF bulldings or apartments?

YES NO

IF YOU ANSWERED YES AND USE A RECOMMENDED MEASURES LIST OR PRIORITY LIST, PLEASE ATTACH A COPY OF THE LIST OR WRITE IN THE LIST BELOW.

IF YOU ANSWERED NO, EXPLAIN HOW MEASURES FOR HDMF BUILDINGS ARE SELECTED. 


$$
\text { A }-4
$$

4. (cont'd) Do you currently have a recommended measures list, a priority list of measures, or a special energy audit measure selection method specincally for HDMF bulldings or apartments?

IF YOU ANSWERED YES AND USE A SPECIAL ENERGY AUDIT MEASURE SELECTION METHOD, PLEASE ATTACH A WRITTEN DESCRIPTION OF THIS METHOD OR WRITE THE DESCRIPTION BELOW. PLEASE INDICATE WHAT BUILDING CC MPONENTS (e.g., boilers, windows, attics) ARE COVERED BY THIS METHOD.

5. Are you aware of any strategic partnerships between WAP providers and other organizations used currently in your State that help bring special expertise to services provided to HDMF buildings?

YES NO

IF YOU ANSWERED YES, PLEASE DESCRIBE THE NATURE OF THESE PARTNERSHIPS BELOW. 


$$
\text { A }-5
$$

6. Do agencies in your State currently have dimculties in qualifying entire IIDMF bulldings or in implementing the $66 \%$ rule for WAP participation?

YES NO

IF YOU ANSWERED YES, DESCRIBE THE ROOT CAUSES OF THESE DIFFICULTIES.

IF YOU ANSWERED YES, DO YOU HAVE SPECIFIC PROCEDURES OR METHODS IMPLEMENTED OR PLANNED TO REDUCE THESE DIFFICULTIES?

YES NO

IF SPECIFIC PROCEDURES OR METHODS FOR REDUCING THESE DIFFICULTIES ARE IMPLEMENTED OR PLANNED, PLEASE ATTACH A WRITTEN COPY OF THE PROCEDURES OR MATERIAL DESCRIBING THE METHODS, OR SUMMARIZE THIS INFORMATION BELOW. 


$$
\text { A }-6
$$

7. Does your State currently require contributions from HDMF building landlords as part of weatherizing such bulldings with WAP funds?

YES NO

IF YOU ANSWERED YES, PLEASE ATTACH A WRITTEN DESCRIPTION OF THESE POLICIES, OR WRITE THE DESCRIPTION BELOW.

WERE LANDLORD CONTRIBUTIONS REQUIRED IN PY 1989?

YES NO

CAN YOU PROVIDE THE EXTENT OF LANDLORD CONTRIBUTIONS TO WEATHERIZATION OF HDMF BUILDINGS FOR YOUR ENTIRE STATE IN PROGRAM YEAR 1989?

TOTAL LANDLORD \$ INVESTED \$

YES NO

LANDLORD $\$$ AS \% OF WAP FUNDS

Other

8. Has your State considered or implemented any changes in policies since PY 1989 intended to improve the WAP services you could offer to HDMF buildings?

YES NO

IF YOU ANSWERED YES, PLEASE ATTACH A WRITTEN DESCRIPTION OF THESE CHANGES IN POLICIES, OR WRITE THE DESCRIPTION BELOW. INDICATE WHETHER THE CHANGE IS IMPLEMENTED OR ONLY CONSIDERED. 


$$
\text { A }-7
$$

9. Do you have training programs in your State that specincally address weatherization services in HDMF buildings or apartments for subgrantees and State starr?

YES NO

If yes, do the HDMF portions of these training programs cover:

Energy audits

Building recruitment procedures

Landlord agreements

Client education (renters)

Building operator education

Identification of major infiltration

Major infiltration measures

Attic insulation

Ventilation

Domestic water heating system retrofits

Heating system retrofits

Distribution system balancing or repair

Wall insulation

Lighting retrofits (as with landlord funds)

Floor insulation

Sill box (or similar) insulation

Window/door retrofits

Duct sealing or duct/pipe insulation

Cooling system retrofits

Other

$\begin{array}{ll}\text { Yes } & \text { No } \\ \text { Yes } & \text { No } \\ \text { Yes } & \text { No } \\ \text { Yes } & \text { No } \\ \text { Yes } & \text { No } \\ \text { Yes } & \text { No } \\ \text { Yes } & \text { No } \\ \text { Yes } & \text { No } \\ \text { Yes } & \text { No } \\ \text { Yes } & \text { No } \\ \text { Yes } & \text { No } \\ \text { Yes } & \text { No } \\ \text { Yes } & \text { No } \\ \text { Yes } & \text { No } \\ \text { Yes } & \text { No } \\ \text { Yes } & \text { No } \\ \text { Yes } & \text { No } \\ \text { Yes } & \text { No } \\ \text { Yes } & \text { No } \\ \text { Yes } & \text { No }\end{array}$

IF YOU ANSWERED YES FOR “OTHER" ABOVE, PLEASE DESCRIBE THE COVERAGE OF THE OTHER TRAINING BELOW. 


$$
\text { A }-8
$$

10. Do you have any suggestions for changes in policies of the U.S. Department of Energy that would improve the WAP services you could offer to HDMF buildings?

YES

NO

IF YOU ANSWERED YES, PLEASE ATTACH A WRITTEN DESCRIPTION OF THESE SUGGESTED CHANGES IN POLICIES, OR WRITE THE DESCRIPTION BELOW.

11. Provide any other comments on HDMF program methods, procedures, obstacles, or potential aids or improvements to WAP efforts on these multifamily buildings. 


\section{APPENDIX B}

\section{National Evaluation of the DOE Weatherization Assistance Program Building Specific Data Survey Form High-Density Multifamily Units for Program Year 1989}

Please provide the name(s) and telephone number(s) of the staff member(s) completing these forms, in case we have questions about the answers.

Name:

AGENCY ID

Phone \#:

\section{INSTRUCTIONS}

1. Please provide the information for this form BY BUILDING. One completed form is needed for each building you describe. If you weatherized several apartment dwelling units in one building, you can describe all dwellling units for that building with one form. You may use more than one form per building if needed, but DO NOT include dwelling units from multiple buildings on the same form.

2. Please copy this form as needed to provide extra copies, if necessary. The number of forms sent to you was estimated and may not be exact. A list of the dwelling units for which data is requested is included with the letter you received. Identification numbers are included on this list. PLEASE ENTER THE DWELLING IDENTIFICATION NUMBERS FROM THE LIST FOR ALL DWELLING UNITS DESCRIBED IN THIS FORM.

3. The phrase "dwelling units reported here" is used in this form to refer to all the dwelling units in one building being described on the following pages.

DWELLING IDs

4. Please provide answers to questions which request numeric values, even if you have to estimate. You can write in the margins if your answer is a wild guess, you are only $50 \%$ sure, or whatever. 
NOTE: These forms need to be completed ONLY ONCE for an entire building.

\section{A. BUILDING CHARACTERISTICS AND EQUIPMENT}

A1. When was the weatherization completed on the dwelling units described below?

Month

(CIRCLE YEAR) 1989

$1990^{*}$

*If the partial or complete multifamily building described below was not weatherized between April 1, 1989 and March 31, 1990, it should not be in the sample and no further information is needed. Please return this form along with the others.

A2. Is this building a... ? (MARK ONE)

[ ] Large multifamily (5 or more units), not owned by a public housing authority (which allows HUD Section 8 dwellings)

[] Large multifamily owned by a public housing authority

[] Any other type of dwelling, including row housing**

**If this dwelling is NOT part of a large multifamily building, it should NOT be in the sample and no further information is needed. Single-family dwellings, including those attached on the sides-sometimes called row housing, should NOT be in the sample and no further information is needed. Please return this form along with the others.

A3. How many dwelling units are covered by the data reported below:

Enter number of units

A4. What is the TOTAL number of all apartment dwelling units in the same building as those described below:

Enter number of units

A5. Did the weatherization work cover the whole building?

(CIRCLE ANSWER) YES NO 


$$
\text { B - } 3
$$

A6. At the time of weatherization, what was the conditioned (heated or cooled) square footage of the areas of the building reported here, where weatherization work was performed? Include common areas if work was performed there (only once for any given building). If an entire building was treated, you must allocate all the conditioned common areas the easiest way for you (including providing a separate set of these forms for the common areas) without double counting.

conditioned square feet

A7. About when was this building originally built? (MARK ONE)
[ ] Before 1900
[ ] 1900-1909
[ ] 1920-1929
[ ] 1950-1959
[ ] 1930-1939
[ ] 1960-1969
[ ] 1910-1919
[ ] 1940-1949
[ ] 1970-1979
[ ] $1980-1984$
[ ] $\begin{gathered}1985 \text { or } \\ \text { later }\end{gathered}$

A8. At the time of weatherization, what was the one main heating fuel used for heating this building? (MARK ONLY ONE FUEL IN COLUMN A8)

A9. What supplemental fuels were used to heat the parts of the building reported here - including those used to provide heat just occasionally? Include fuels that ran portable heaters if they were used. Mark all that apply (If none, mark "No supplemental fuels used" in Column "A9" below.)

A8

Main Fuel (Mark only one)
A9 Supplemental Fuels (Mark all that apply)

Gas from underground pipes serving the neighborhood $\ldots \ldots \ldots$

Bottled gas (LPG or Propane)........

Fuel oil.................

Kerosene or coal oil. . . . . . . . . .

Electricity. ................

Coal or coke. . . . . . . . . . . .

Wood.

Solar collectors. . . . . . . . . . .

Other (specify)

No supplemental fuels used. $\ldots \ldots \ldots \ldots \ldots \ldots \ldots$

Don't know.................

[]

[ ]
$[3]$
[]
[ ]
[ ]
[ ]
[ ]
[ ]
[ ]
[ ]

A10. If this building's main heating fuel is fuel oil, please provide the name of the fuel oil dealers that provide service to this dwelling. Also provide the city where the dealer is located. 


$$
\text { B }-4
$$

A11. What heating system types were used for this building?

(MARK ALL THAT APPLY)

[ ] Apartment central systems (e.g., furnace with ducts, hot water boiler, heat pump with ducts) with one system per apartment dwelling

[ ] Building central systems (e.g., central furnace, steam boiler, hot water boiler) serving multiple apartment dwellings in the building

[ ] Fossil fueled in-space heaters (e.g., wall furnaces, floor funaces, wood, coal, kerosene or gas stoves)

[ ] Electric in-space heaters (e.g., through-the-wall heat pumps, wall, floor, baseboard, imbedded cable, portable [cord connected])

[ ] Other (specify)

[] Don't know

A12. Does this building have central air conditioning (A/C) equipment? (MARK ALL THAT APPLY)

[ ] Apartment central $\mathrm{A} / \mathrm{C}$ with one system per apartment dwelling

[ ] Building central $\mathrm{A} / \mathrm{C}$ with one system serving the whole building

[ ] Other central A/C

[ ] No central air conditioning for apartment dwellings

[ ] Don't know

A13. How many wall or window air conditioner or heat pump units were in the dwelling units reported here? (MARK ONE - PLEASE ESTIMATE IF NOT SURE)
[ ] None
[ ] 1.4
[ ] 10-29
[] $5-9$
[] 30 or more
[ ] Don't know

A14. What domestic hot water system types were used for this building? (MARK ALL THAT APPLY)

[ ] Central system for the whole building

[] Central systems serving each floor

[ ] Individual units in the dwelling units

[ ] Circulating loop

[] Circulating loop

[] Other (specify)

[] Don't know 


\section{B. OCCUPANT CHARACTERISTICS}

B1. If the entire building was included in the weatherization work, was the building qualified under the $66 \%$ rule?

$$
\text { (CIRCLE ANSWER) YES NO }
$$

B2. Please indicate: the total number of people living in the dwelling units reported here, the number who had income eligibility for the WAP verified for the 1989 program year before weatherization, and the total number of people in the building (estimate if you do not know). Also, please indicate the number who were elderly or handicapped.

Total number reported here:

Number of income-verified:

Total number of people in the building:

Number of elderly (age 65 or over):

Number of handicapped (permanent condition):

B3. For all households reported here, where income eligibility was verified and an application form was received, what is the average of all these incomes?

$\$ / y r$

B4. At the time of weatherization, how many households reported here for which an application form was received:

Rented their apartment dwelling

Occupied without payment

Owned (are buying) their dwelling

Enter the appropriate number of units for each line

B5. At the time of weatherization, how many households reported here for which an application form was received:

Paid their own fuel bills for heating

Paid for heating fuel through their rent

Enter the appropriate number of units for each line 


\section{WEATHERIZATION MEASURES INSTALLED}

Please check any of the measures listed that were installed in this dwelling. Include measures for common areas (can be with one or more units or as a special unit by itself), but note that the measure is for a common area. Indicate whether the measures were installed by in-house crew or contractor. If measures that are not listed were installed, please describe them in the appropriate "Other" category.

Installed by:

In-house Contractor crew

C1. Air Leakage Control

General Caulking and Weatherstripping ........ (door, window, sill plates, etc.)

Air Sealing, emphasizing bypasses with ........ blower door testing

Air Sealing, emphasizing bypasses without ....... blower door testing

Air Distribution System. . . . . . . . . . . . . .

Other Infiltration Reduction (not including windows)

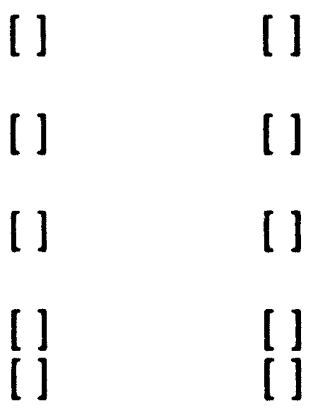

(Specify:

C2. Insulation

Attic Insulation (installed for the first time).......

Attic Insulation (added to existing insulation). . . . . .

*Wall Insulation (normal technique). ..........

*Wall Insulation (high-density technique). . . . . . .

Floor Insulation. . . . . . . . . . . . . . .

Rim or Band Joist Insulation. . . . . . . . . . .

Other Envelope Insulation.

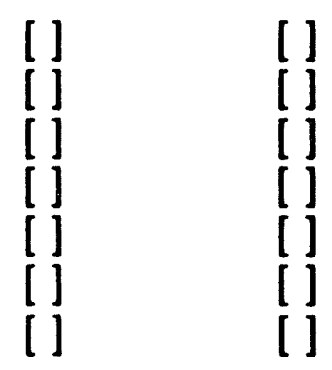

(Specify:

*The "normal technique" for installing wall insulation is characterized by blowing cellulose or fiberglass insulation into exterior wall cavitites to average densities using a two-hole, gravity-blow installation method. The "high-density technique" is characterized by blowing cellulose insulation into exterior wall cavities to high densities using a one-hole, tube-fill installation method. Under the "high-density technique," special attention is focused on sealing air leakage sites while insulating the walls; air bypasses are identified during the installation process and sealed by plugging the air-leakage pathways with cellulose. 
C3. Water Heating System

Installed by:

In-house Contractor

crew

What type of water heating system is in the building?

Individual for this unit [] Central for all units [] Other

Water Heater Tank Insulation. .............

Entire Water Heating Unit Replacement. . . . . . . . .

Central System Controls Improvements . . . . . . . .

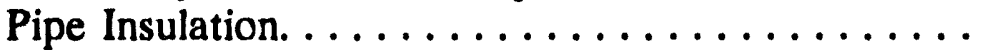

Low Flow Shower Heads or Faucet Aerators . . . . . .

Temperature Reduction. ...............

Other Water Heater Measures or Repairs. ........

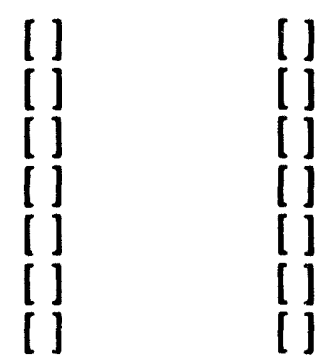

(Specify:

C4. Space Heating System

What type of space heating system is in the building?

Individual for this unit [] Central for all units [ ] Other

Clean and Tune-up...................

Thermostat or Other Controls Retrofit.

[]

[]

(Specify:

Entire Heating Unit Replacement/Modification. . .

Repairs. .....................

[ ]

[]

$\left.\begin{array}{l}{[]} \\ {[]} \\ {[]} \\ {[]} \\ {[]} \\ {[]}\end{array}\right]$

(Specify:

Was replacement/modification or repair expected to increase energy use? (CIRCLE ANSWER) YES

NO

Distribution System Retrofit (e.g., steam balancing)

[ ]

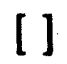

(Specify:

Heating System Component Retrofits.

[ ]

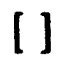

(Specify:

Safety Problem Fixed.

[]

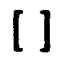

(Specify:

Other Heating System Modifications 
C5. Space Cooling System

Installed by:

In-house Contractor crew

What type of space cooling system is in the building?

Individual for this unit [] Central for all units [] Other

Tune-up. ........................

(e.g., cleaning, controls adjustment, filter replaced)

Entire Air-Conditioning System Replacement ......

Fans Installed or Replaced. ...............

Thermostat or Other Controls Retrofit. ........

(Specify:

Distribution System Retrofit (e.g., duct sealing/balancing) [ ] [ ]

(Specify:

Other Cooling System Modifications. ..........

(Specify:

C6. Ventilation System

Controls Retrofit..................

[ ]

(Specify:

[ ]

(Specify:

Other Repairs.

[]

(Specify:

Other Ventilation System Modifications.

[]

(Specify:

C7. Windows and Doors

Storm Windows (How many?

Thermal Windows (How many?

[ ]

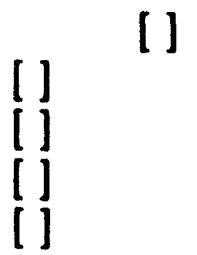

[]

Storm Doors. ....................

Window Films or Shades.

Other Window or Door Treatments.

(Specify: 
C8. Structural Repairs (full or partial)

Attic Ventilation. . . . . . . . . . . . .

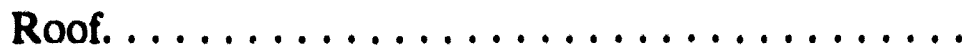

Ceilings. . . . . . . . . . . . . . . . . .

Doors.

Replacement of Doors. . . . . . . . . . . . . .

Windows/Glazing. ................

Walls. . . . . . . . . . . . . . . . .

Floor.

Other Structural Repairs.

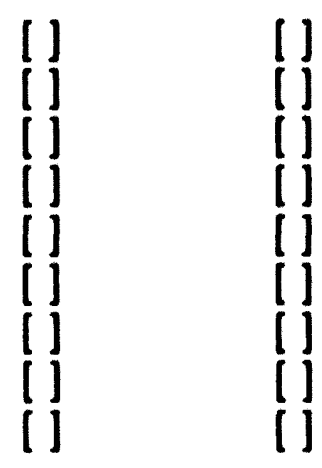

(Specify:

C9. Other Health and Safety Repairs or Improvements

Smoke Detectors. . . . . . . . . . . . . . . .

Interior Fire Doors.

Railings. . . . . . . . . . . . . . . .

Stairs/Ramps. . . . . . . . . . . . . . .

Locks. . . . . . . . . . . . . . . . . .

Radon Testing. . . . . . . . . . . . . . . .

Carbon Monoxide Testing. . . . . . . . . . . .

Backdrafting Testing. . . . . . . . . . . . .

Other. ......................

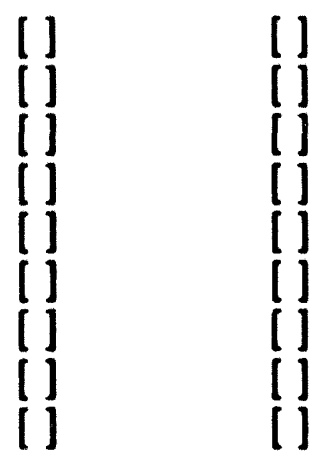

(Specify:

\section{SERVICE DELIVERY PROCEDURES}

\section{D1. SELECTION OF MEASURES}

Please check the type of procedure that was used to select the measures that were installed in the dwellings reported here in the 1989 program year. (Check all that apply)

\section{Envelope Measures}

[ ] Envelope measures were selected using a priority or prescribed list of measures

[] Envelope measures were selected using a decision approach or scoring (calculation) developed for each house

[] Envelope measures were selected based on an analysis of energy savings per \$ invested 


\section{D1. SELECTION OF MEASURES (continued)}

Space Heating-Cooling-Ventilation (HVAC) System Measures

[1] HVAC system measures were selected based on physical characteristics of pre-retrofit unit or a standard approach (similar to a priority list)

[1 HVAC system measures were selected using a decision approach or scoring (calculations) based on operating performance

[1 HVAC system measures were selected based on an analysis of energy savings per $\$$ invested

\section{Domestic Water Heating (DHW) System Measures}

[ ] DHW system measures were selected based on physical characteristics of pre-retrofit unit or a standard approach (similar to a priority list)

[1 DHW system measures were selected using a decision approach or scoring (calculations) based on operating performance

[ ] DHW system measures were selected based on an analysis of energy savings per $\$$ invested

\section{General}

[ ] Selection of envelope and HVAC and DWH energy system measures was made simultaneously under one approach rather than separately using distinct procedures.

[ ] Investment level per unit was determined based on analysis of preweatherization energy consumption data.

[] Outside consultant specialists were used.

[ ] Other measure selection procedures. Specify: 


\section{D2. USE OF DIAGNOSTICS}

Please check the type of diagnostic procedures that were used. (Check all that apply)

[] Blower door testing was used to find leakage areas for sealing

[1 Blower door testing was used to measure air leakage rates

[1 Blower door testing was used to determine when to stop work using cost-effectiveness guidelines (not minimum ventilation guidelines)

[1 Distribution system diagnostics were used to determine system balancing

[] Distribution system diagnostics were used to seal leaks

[] Infrared scanning was used

[] Indoor air quality was tested

1] Heating, cooling, or domestic water heating system efficiency testing was used

[] Combustion systems safety inspections were conducted

[] Other diagnostic procedures. Specify:

\section{D3. QUALITY CONTROL}

Please indicate the type of quality control inspection used. (Check all that apply)

[] A visual quality control inspection after weatherization for envelope measures

[] A quality control inspection after weatherization for envelope measures that used blower door testing as a diagnostic tool

[] A quality control inspection after weatherization for envelope measures that used infrared scanning as a diagnostic tool

[1 A visual quality control inspection after weatherization for heating system measures

[1 A quality control inspection after weatherization for heating system measures that used diagnostic tools such as combustion efficiency testing

[ ] Other quality control procedures. Specify: 


$$
\text { B }-12
$$

\section{E. COSTS: MATERIALS, LABOR, INSTALLATION OVERHEAD AND PROGRAM MANAGEMENT}

\section{Definitions and Instructions}

If a job is crew-based, supply the materials costs (Question E1) and calculate the direct labor costs (Question E2). If a job is contractor-based, supply the materials costs (Question E1) and the total installed costs (Question E3). If both crews and contractors worked on a building, complete all three questions (Questions E1, E2, and E3). You should already have examined this information for the forms completed for the Single-Family Study.

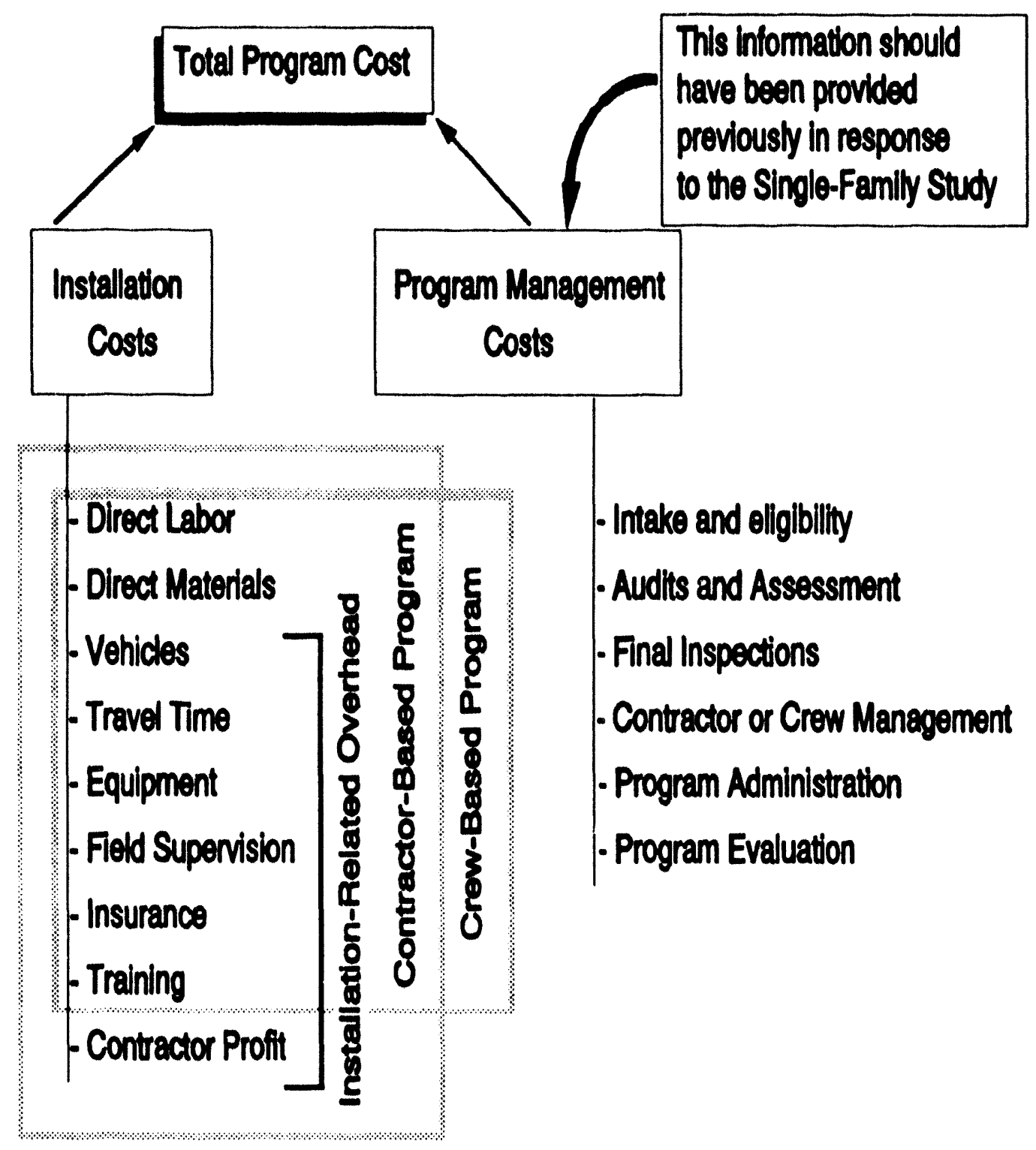




$$
\text { B }-13
$$

\section{E1: BREAKDOWN OF MATERIALS COSTS}

In the chart below please fill in the crew-based and/or contractor-based materials cost of the measures that were installed in the dwelling units reported here for the 1989 program year. Do not include labor, administrative or program support costs here. Do include costs covered by all sources of funding (i.e., PVE, LIHEAP, landlords, or utilities). Costs covered by landlord contributions that do not contribute directly to energy savings can be included under Structural Repairs, with a note explaining why. If you cannot provide the costs by general type of measure, just enter the total materials cost in the box at the buttom.

\section{Crew-Based \\ Materials \\ Costs}

Air Leakage Control

Insulation

attic

wall

other

Water Heating System

retrofit

replacement

Space Heating System

retrofit

replacement

Space Cooling System

retrofit

replacement

Ventilation System

retrofit

replacement

Windows and Doors

Structural Repairs

Other

TOTAL Materials Costs
$\$$
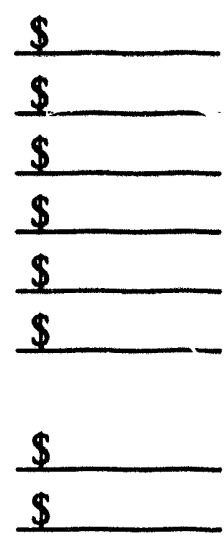

Contractor-Based

Materials

Costs

$\$ \$$

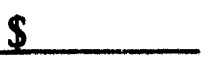

$\$$

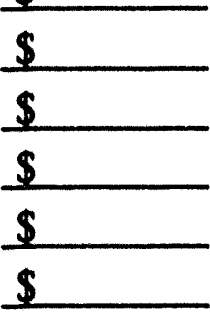

$\$$

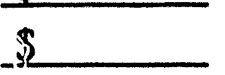

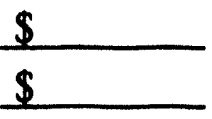

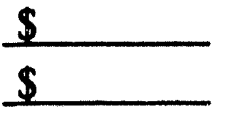

$\$$

$\$$
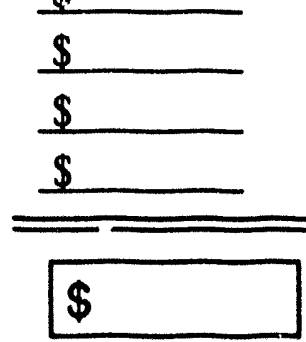

$\$$

$\$$

$\$$

$\$$

$\$$

$\$$

Crew-Based

Contractor-Based 


\section{E2: CREW-BASED INSTALLATION COSTS (DIRECT LABOR COSTS)}

Directions: Please fill in the number of crew hours for the dwellings reported here from information in your files. Provide your best estimate of the average hourly rate for your crew and multiply this by the number of hours to produce an estimate of the direct labor costs.

DO NOT include ANY OVERHEAD (as shown in Fig. 1) in the average hourly rate.

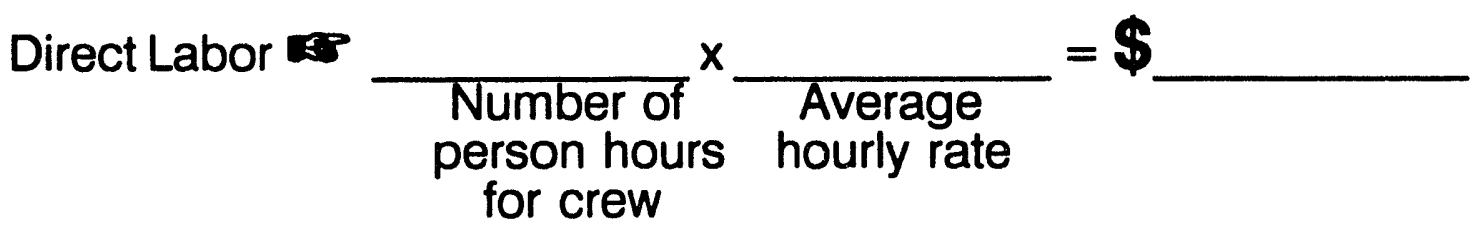

\section{E3: CONTRACTOR-BASED INSTALLATION COSTS}

Directions: Please fill in the total installation costs* billed by contractors for the dwellings reported here. This should include all the overhead cost categories listed in Fig. 1 plus the contractor's profit.

Total Installed Cost \$

*Include the materials costs (reported on p. 13) in this total, as well as labor costs and installation-related overhead.

\section{F. FUNDING SOURCES}

F1. What percentage of the funds spent on the dwellings reported here were:

Funds from DOE's WAP:

Funds from Landlord:

Funds from Others:

$\overbrace{\%}^{\%} \%$

F2. If funds from non-DOE sources were used, were they all used according to DOE guidelines?

[ ] Yes

[] No 


\section{INTERNAL DISTRIBUTION}

$\begin{aligned} 1 & \text { R.A. Balzer, 4500N, MS } 6206 \\ 2 & \text { D.C. Bauer, 4500N, MS } 6206 \\ 3 & \text { L.G. Berry, 4500N, MS } 6206 \\ 4 & \text { M.A. Brown, 4500N, MS } 6206 \\ 5 & \text { R.S. Carlsmith, 4500N, MS } 6188 \\ 6 & \text { C.V. Chester, 4500N, MS } 6190 \\ 7 & \text { S.M. Cohn, 4500N, MS } 6205 \\ 8 & \text { J.W. Cooke, 4500N, MS } 6269 \\ 9 & \text { G.E. Courville, 3147, MS } 6070 \\ 10 & \text { T.R. Curlee, 4500N, MS } 6205 \\ 11 & \text { S. Das, 4500N, MS 6205 } \\ 12 & \text { W. Fulkerson, 4500N, MS } 6247 \\ 13 & \text { M.B. Gettings, 3147, MS } 6070 \\ 14 & \text { S.W. Hadley, 4500N, MS } 6206 \\ 15 & \text { L.J. Hill, 4500N, MS } 6205 \\ 16 & \text { E.L. Hillsman, 4500N, MS } 6206 \\ 17 & \text { E. Hirst, 4500N, MS 6206 } \\ 18 & \text { R.B. Honea, 4500N, MS } 6179 \\ 19 & \text { P.J. Hughes, 3147, MS C070 } \\ 20 & \text { M.A. Karnitz, 4515, MS } 6065 \\ 21 & \text { C.R. Kerley, 4500N, MS } 6205 \\ 22 & \text { J.O. Kolb, 3147, MS } 6070 \\ & \end{aligned}$

$\begin{aligned} 23 & \text { M.A. Kuliasha, 4500N, MS 6189 } \\ 24 & \text { W.P. Levins, 3147, MS 6070 } \\ 25 & \text { H.A. McLain, 3147, MS 6070 } \\ 26 & \text { J.M. MacDonald, 3147, MS 6070 } \\ 27 & \text { W.R. Mixon, 3147, MS 6070 } \\ 28 & \text { R.L. Noe, 4500N, MS 6206 } \\ 29 & \text { D.E. Reichle, 4500N, MS 6253 } \\ 30 & \text { A.C. Schafthauser, 4500N, MS 6186 } \\ 31 & \text { M. Schweitzer, 4500N, MS 6206 } \\ 32 & \text { T.R. Sharp, 3147, MS 6070 } \\ 33 & \text { R.B. Shelton, 4500N, MS 6187 } \\ 34 & \text { B.M. Sorensen, 4500N, MS 6190 } \\ 35 & \text { M.P. Ternes, 3147, MS 6070 } \\ 36 & \text { B.E. Tonn, 4500N, MS 6207 } \\ 37 & \text { D.L. White, 4500N, MS 6206 } \\ 38 & \text { T.J. Wilbanks, 4500N, MS 6184 } \\ 39-338 & \text { Section Distribution, 3147, MS } 6070 \\ 339 & \text { ORNL Patent Office } \\ 340 & \text { Central Research Library } \\ 341 & \text { Document Reference Section } \\ 342-344 & \text { Laboratory Records (3) } \\ 345 & \text { Laboratory Records - RC } \\ & \end{aligned}$

\section{EXTERNAL DISTRIBUTION}

346 D.A. Beschen, U.S. Department of Energy, 5G-023, EE-70, 1000 Independence Ave., S.W., Washington, DC 20585

347 D.R. Bohi, Director, Energy and Natural Resources Division, Resources for the Future, 1616 P Street, N.W., Washington, DC 20036

348 P. Brandis, Office of Energy Resources, Bonneville Power Administration, P.O. Box 3621, Portland, OR 97208

349 T.E. Drabek, Professor, Department of Sociology, University of Denver, Denver, Colorado 80208-0209

350 M.A. Fowler, U.S. Department of Energy, SG-023, EE-532, 1000 Independence Avenue, S.W., Washington, DC 20585

351 C.D. MacCracken, President, Calmac Manufacturing Corporation, 101 West Sheffield A ve., P.O Box 710, Englewood, NJ 07631

352 Ralph Nader, Post Office Box 19367, Washington, DC 20036

353 Office of Assistant Manager for Energy Research and Development, DOE Oak Ridge Field Office, P.O. Box 2008, Oak Ridge, TN 37831-6269

354 OSTI, U.S. Department of Energy, P.O. Box 62, Oak Ridge, TN 37831

355 J.B. Shrago, Director, Office of Technology Transfer, Vanderbilt University, 405 Kirkland Hall, Nashville, TN 37240

356 G.F. Sowers, P.E., Senior Vice President, Law Companies Group, Inc., 114 Townpark Drive, Suite 250, Kennesaw, Genrgia 30144-5599

357 J. Van Vlandren, U.S. Department of Energy, EE-532, 1000 Independence Ave., S.W., Washington, DC 20585

358 C.M. Walton, Ernest H. Cockrell Centennial Chair in Engineering and Chairman, Department of Civil Engineering, College of Engineering, The University of Texas, Cockrell Hall, Suite 4.2, Austin, Texas 78712 
$1 !$
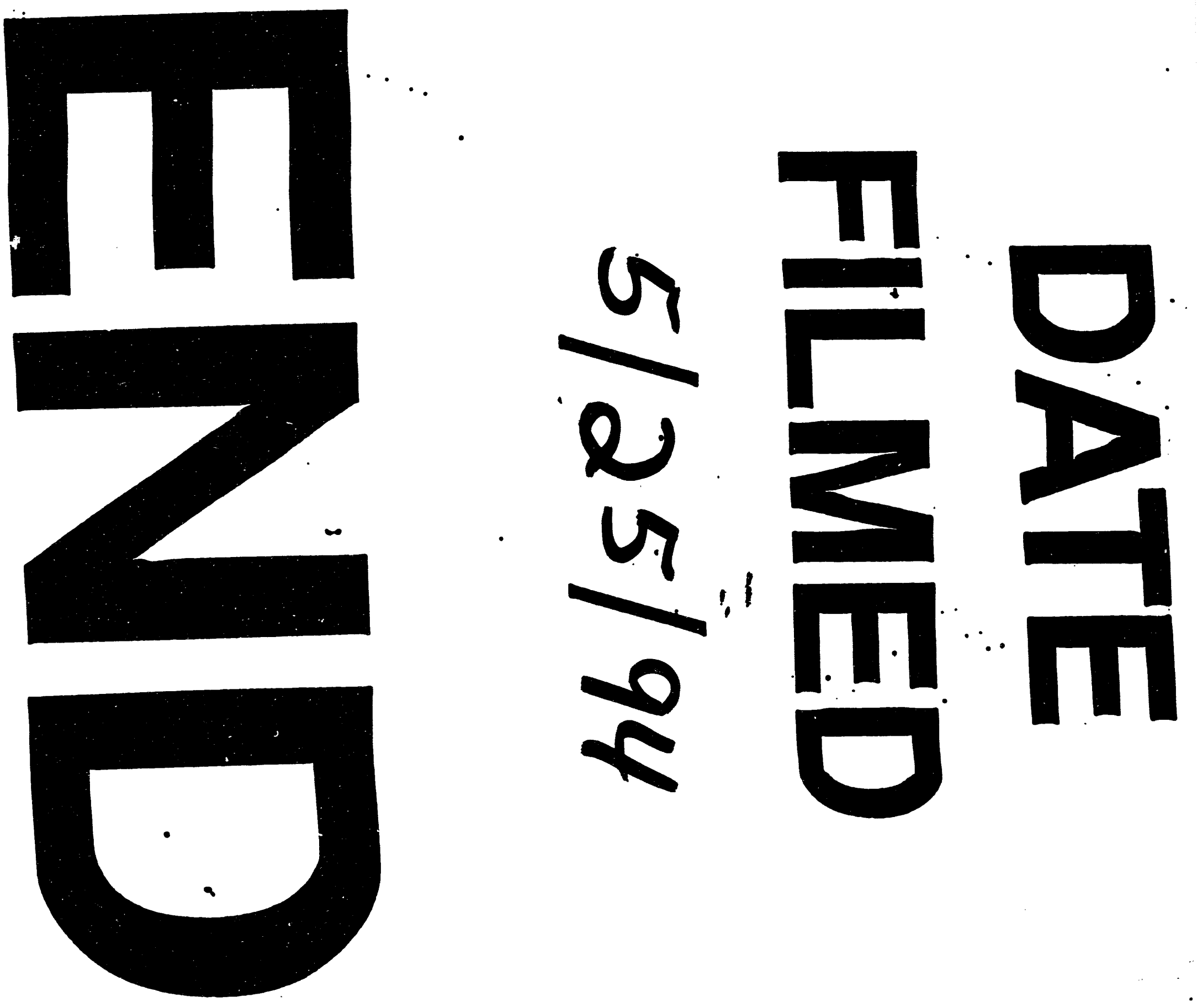


$$
-
$$

